\title{
The use of interprofessional simulation interventions in medical student education: A scoping review
}

\author{
V. Langton ${ }^{1,2}$, D. Dounas ${ }^{2}$, A. Moore ${ }^{2}$, S. Bacchi ${ }^{1,2} \& J$. Thomas $^{1,2}$
}

\begin{abstract}
Introduction: Simulation is commonly used by health and education institutions to facilitate interprofessional learning (IPL). The use of simulation in IPL is resource intensive. Evidence of what works, and with whom, is important to inform practice, policymaking and further research. The aim of this scoping review was to summarise the existing literature on IPL involving medical students, where simulation was the teaching modality. This review examined a variety of simulation-based interventions used to teach IPL to medical students and identified key features and outcomes.

Methods: The databases PubMed, Medline, EMBASE and PsychINFO were searched using the terms related to medical student and simulation combined with interprofessional. Included articles involved medical students alongside a student or practitioner from at least one other health profession taking part in at least one simulation session. Data extraction was performed by two authors using a standardised form.
\end{abstract}

Results: It emerged that simulations of medical emergencies were the most common format to deliver IPL interventions. Most studies evaluated the success of their IPL intervention using the Readiness for Interprofessional Learning Scale (RIPLS).

Conclusion: All studies were successful in improving student attitudes towards IPL and interprofessional collaboration when these were measured outcomes. Formal team training prior to simulation is effective in improving teamwork skills. IPL interventions with participants from a greater mix of professions have more positive results.

Keywords: interprofessional learning; interprofessional education; medical students; simulation; simulation training

\footnotetext{
1 Royal Adelaide Hospital

2 University of Adelaide 
THE USE OF INTERPROFESSIONAL SIMULATION INTERVENTIONS IN MEDICAL STUDENT EDUCATION

\section{Introduction}

Interprofessional learning (IPL) is currently included in many health curricula, with the aim of improving collaborative behaviours. It is defined by the World Health Organisation (WHO) (2010) as when "students from two or more professions learn about, from and with each other to enable effective collaboration and improve health outcomes" (p. 13). In particular, the aim of IPL is to develop teamwork capabilities and collaborative behaviours.

Many institutions use simulation-based activities to facilitate IPL, with the aim of preparing health professionals for the challenges and pressures they will face in the workplace. Simulation as a teaching modality for IPL enables a broad scope of both complexity and flexibility of learning and is therefore suitable for learners at multiple levels of training and experience (undergraduate, postgraduate and post-qualification) (Poore et al., 2014). A wide variety of simulation interventions have been used in IPL, ranging from highfidelity simulations involving technologically-advanced mannequins replicating diverse clinical scenarios (Appelbaum et al., 2020; Brown et al., 2016) through to semi-structured interviews with simulated patients, using human actors (Atack et al., 2009; Blackhall, Erickson, et al., 2014; Hess et al., 2016; Lee et al., 2019; Tankimovich et al., 2020). Virtual reality is an emerging branch of simulation, which uses computer generation to mimic clinical scenarios and allows learners to emulate the roles of healthcare practitioners with virtual patients, and it may be more cost effective (Liaw, Ooi, et al., 2020). Accordingly, there are large differences between studies examining broadly different interventions, making comparison challenging.

Learner outcomes are commonly evaluated against the Joint Evaluation Team (JET) model of interprofessional outcomes (Freeth et al., 2007). This model is adopted from the widely recognised outcomes framework of Kirkpatrick (2006) for evaluation of training and has been specifically modified for IPL (Thistlethwaite et al., 2015). Originally designed for business organisations, the Kirkpatrick framework considers four learner outcomes: i) "reactions" applicable to their learning needs, ii) "new learning" that is effective and sustainable, iii) "behaviour changes" that lead to doing something different and iv) "results" related to the outcomes of the business. In considering the aims of IPL for improving patient care, the JET model offers more detailed outcome levels. Higher levels in this framework pertain to changes in learners' attitudes, skills and behaviour through to changes in organisational practice and benefits to patients (see Table 1).

IPL implementation is challenging, and barriers are well documented, including timetabling, resources, staff attitudes and skills, professional silos and uniprofessional education programs (Greenstock et al., 2012; Lawlis et al., 2014; Poore et al., 2014). The logistical barriers to synchronising different timetables to bring students together at the same place and time is a significant hurdle. Furthermore, simulation is a resource intensive teaching modality with significant costs in many cases (Lawlis et al., 2014). Despite this, 
THE USE OF INTERPROFESSIONAL SIMULATION INTERVENTIONS IN MEDICAL STUDENT EDUCATION

\section{Table 1}

JET Model of Interprofessional Outcomes* Accompanied by Examples That Include Medical Students Completing IPL Simulation

\begin{tabular}{|c|c|c|c|}
\hline & Outcome Levels & Description & IPL example \\
\hline 1. & Reaction & $\begin{array}{l}\text { Learners' view on the } \\
\text { learning experience and its } \\
\text { interprofessional nature }\end{array}$ & Reaction to the IPL team \\
\hline $2 \mathrm{a}$. & $\begin{array}{l}\text { Modification of } \\
\text { attitudes/perceptions }\end{array}$ & $\begin{array}{l}\text { Changes in reciprocal attitudes } \\
\text { or perceptions between } \\
\text { participant groups. }\end{array}$ & $\begin{array}{l}\text { Perception of another } \\
\text { health professional's role }\end{array}$ \\
\hline $2 b$. & $\begin{array}{l}\text { Acquisition of knowledge } \\
\text { and skills }\end{array}$ & $\begin{array}{l}\text { Acquisition of knowledge } \\
\text { and skills linked to } \\
\text { interprofessional collaboration }\end{array}$ & $\begin{array}{l}\text { Improvement in teamwork } \\
\text { skills }\end{array}$ \\
\hline 3. & Behavioural change & $\begin{array}{l}\text { Identified individuals' transfer of } \\
\text { interprofessional learning to their } \\
\text { practice setting and changes to } \\
\text { professional practice }\end{array}$ & Nil examples in literature \\
\hline $4 a$. & $\begin{array}{l}\text { Change in } \\
\text { organisational practice }\end{array}$ & $\begin{array}{l}\text { Wider changes in the organisation } \\
\text { and delivery of care }\end{array}$ & Nil examples in literature \\
\hline $4 b$. & Benefits to patients/clients & $\begin{array}{l}\text { Improvements in health or } \\
\text { wellbeing of patients/clients }\end{array}$ & Nil examples in literature \\
\hline
\end{tabular}

* Freeth et al., 2007

the use of simulation in IPL has increased in medical education (Freeth et al., 2007). Given the barriers to implementation of IPL and the significant resourcing implications, evidence demonstrating efficacy and supporting ongoing program delivery is useful. We need to be aware of gaps in evidence in order to direct further research efforts. The aim of this study was to conduct a scoping review of the current literature on IPL involving medical students, where simulation was the teaching modality. We sought to identify key outcomes assessed, participants and settings for IPL.

\section{Methods}

We conducted a scoping review using the steps outlined in the Joanna Briggs Institute Reviewers' Manual 2017.

\section{Data sources}

On 14 March 2020, we searched the following four major electronic databases: PubMed, Medline, EMBASE and PsychINFO. Search terms consisted of the medical student terms ("medical student" MeSH heading OR "medical" AND "student" in title/abstract) 
combined with the simulation terms ("simulation" OR "simulation training" MeSH heading or title/abstract) and interprofessional ("interprofessional" in title/abstract). The reference lists of all identified sources were searched for additional sources. Articles published between 2000 and 2020 were included.

\section{Study selection}

Inclusion criteria included (1) primary publication assessing humans, (2) evaluated a simulation intervention, (3) involved medical students alongside a student or practitioner from at least one other health profession (for example, nursing, pharmacy, physiotherapy) and (4) available in full text in English.

Following the application of the English language filter, the title and abstract of these studies were screened independently by two authors for eligibility based on the inclusion criteria. The full text of screened abstracts was then assessed. Disagreements were resolved by discussion until consensus was reached. If there was difficulty in reaching a consensus, a third author reviewed the article in question.

\section{Data extraction}

Data extraction was performed independently by two authors using a predefined standardised charting form. Data extracted included: participants (interprofessional groups involved), sample size, type of simulation intervention, format of simulation intervention, duration of intervention sessions, number/frequency of intervention sessions, presence of a control group, presence of blinding, outcomes assessed and method of outcome assessment. Again, disagreements were resolved by discussion until consensus was reached, and a third author reviewed any articles in which there was difficulty in reaching a consensus.

\section{Data charting and collation}

Data was organised into tables by type of simulation intervention. Data was characterised according to participants (interprofessional groups involved), format of simulation intervention, outcome assessment method and outcomes measured as described in the Joint Evaluation Team (JET) model of interprofessional outcomes (Freeth et al., 2007). The aim of this structure was to efficiently summarise the literature so as to draw links between the format of the simulation intervention and the specific outcomes measured. An additional aim was to demonstrate the common outcome assessment method types that have been used for different simulation formats.

\section{Ethical considerations}

No ethics approval was sought due to the nature of the review. 
THE USE OF INTERPROFESSIONAL SIMULATION INTERVENTIONS IN MEDICAL STUDENT EDUCATION

\section{Results}

A total of 126 studies were identified (see Figure 1).

\section{Figure 1}

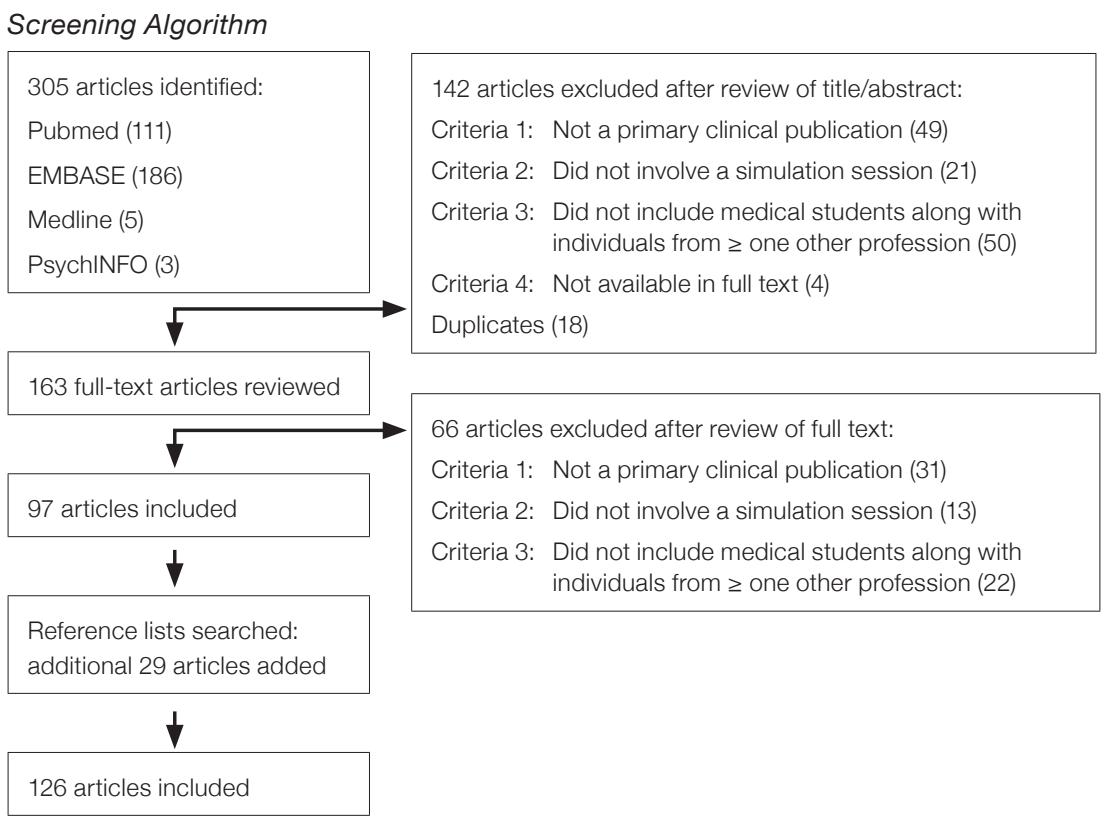

\section{Participants}

All studies involved teaching medical students with a student or practitioner from at least one other health profession (126 studies).

The most common health professional student group to be combined with medical students was nursing (109 studies), followed by pharmacy (32 studies). Other professions combined with medical students included physiotherapy, midwifery, physician's assistants, dentistry and paramedics.

\section{Format of simulations}

A wide variety of formats were used in simulation interventions. Many studies described their intervention as being a high-fidelity simulation, which involved mannequins that simulate life-like physical signs and display physiological information on monitors (AlElq, 2010). Another common format of IPL simulation was creating e-learning tools for students, such as online modules (Berg et al., 2010; Djukic, Adams, et al., 2015; Djukic, Fulmer, et al., 2012; Ellman et al., 2012). Some e-learning tools incorporated virtual reality 
THE USE OF INTERPROFESSIONAL SIMULATION INTERVENTIONS IN MEDICAL STUDENT EDUCATION

\section{Table 2}

Participants in Interprofessional Simulation With Medical Students

\begin{tabular}{l|c}
\hline Two other health professions & 55 studies \\
\hline Three other health professions & 24 studies \\
\hline Four other health professions & 8 studies \\
\hline Five other health professions & 4 studies \\
\hline Six other health professions & 1 study \\
\hline Seven other health professions & 2 studies \\
\hline
\end{tabular}

or telehealth (Liaw, Ooi, et al., 2020; Scott et al., 2020). Frequently, there was a combination of both e-learning tools and high-fidelity simulation within one intervention (Atack et al., 2009; Ellman et al., 2012; Hess et al., 2016; Kearney et al., 2010; J. L. Miller et al., 2014). For example, Atack et al. (2009) offered online modules as preparation for students who were undertaking a high-fidelity disaster simulation. In addition, interventions focusing on communication skills used simulated patients for patient interactions as part of their simulation intervention (Blackhall et al., 2014; C. Cooke et al., 2017; Hess et al., 2016). Some studies included students simply observing discussions with no active participation (Efstathiou \& Walker, 2014; Nystrom et al., 2016).

An assortment of frameworks was used in the design of simulation interventions to teach interprofessional teamwork skills. The most common framework was The Team Strategies and Tools to Enhance Performance and Patient Safety (TeamSTEPPS) (Brock et al., 2013; Fewster-Thuente, 2014; Hobgood et al., 2010; Horsley et al., 2016; Liaw, Siau, et al., 2014; Reed et al., 2017; Robertson et al., 2010). TeamSTEPPS is a curriculum designed for interprofessional health teams, focusing on team leadership and communication skills (Brock et al., 2013; Liaw, Siau, et al., 2014; Robertson et al., 2010). Another popular framework was Crisis Resource Management (CRM) skills (Kyrkjebo et al., 2006; Shrader, Kern, et al., 2013; Sigalet, Donnon, Cheng, et al., 2013; Sigalet, Donnon, \& Grant, 2015; Smithburger et al., 2013). Initially developed for use in aviation, this framework has been adapted for the healthcare setting and emphasises important non-technical teamwork skills, such as communication, situational awareness and decision making to promote safety and increased efficiency of healthcare teams (Sigalet, Donnon, Cheng, et al., 2103)

\section{Content of simulations}

There was a variety of content included in simulation interventions. The two most common themes were emergency scenarios (see Appendix A) and communication skills (see Appendix B). Appendix A (51 studies) includes studies that used an emergency 
THE USE OF INTERPROFESSIONAL SIMULATION INTERVENTIONS IN MEDICAL STUDENT EDUCATION

scenario to develop students' clinical skills in acute care (basic life support, advanced life support and trauma management). Appendix B (32 studies) includes studies that aimed to teach communication skills. The remaining studies encompass a variety of simulation interventions, including simulated ward rounds and simulated procedures. Four studies used a high-fidelity IPL simulation of a hospital ward round to provide a setting for students to practise communicating while participating in the management of a patient (Joyal et al., 2015; Ker et al., 2003; Nikendei et al., 2016; Shrader, McRae, et al., 2011). Four studies used a high-fidelity IPL simulation intervention in the context of teaching procedures related to obstetrics (Gorantla et al., 2019; Kumar, Gilmour, et al., 2014) and general surgery (Paige et al., 2014; Wang et al., 2015) on mannequins.

\section{Outcome assessment methods}

Outcomes were most frequently evaluated by collecting data from pre- and postintervention survey responses or focus group discussions to explore students' experiences of the simulations (See Appendix A and Appendix B). The Readiness for Interprofessional Learning Scale (RIPLS) was the most common assessment tool. It is a self-reported questionnaire undertaken before and after the simulation intervention and is designed to measure changes in attitudes and perceptions towards IPL (Parsell \& Bligh, 2002). The KIDSIM team performance questionnaire is also designed to measure students' attitudes towards IPL. Sigalet, Donnon and Grant (2012) designed a study involving medical, nursing and respiratory therapy students participating in an IPL simulated emergency scenario that confirmed the reliability of the KIDSIM questionnaire in assessing attitude changes. Other surveys used as assessment tools included the Communication and Teamwork Skills (CATS) assessment tool (Garbee et al., 2013; Smithburger et al., 2013) and the Attitudes Toward Health Care Teams survey (Wamsley et al., 2012), but these were used less frequently. In terms of focus groups, six studies evaluated the impact of their IPL simulation intervention using a semi-structured format to facilitate discussion and reflection between small groups of participating students (Kumar, Wallace, et al., 2017; Nikendei et al., 2016; Reime, Johnsgaard, Kvam, Aarflot, Breivik, et al., 2016; Reime, Johnsgaard, Kvam, Aarflot, Engeberg, et al., 2017; Rodehorst et al., 2005; Whelan et al., 2008). The aim of the focus groups was to achieve a more detailed understanding of students' attitudes towards the intervention.

Apart from validated survey responses and focus group discussions, several researchers chose to create their own surveys and assessment criteria, using tools such as the Interdisciplinary Education Perception Scale (IEPS) as a framework (Baker et al., 2008; Bottenberg et al., 2013; New et al., 2015; Shrader, Kern, et al., 2013) (See Appendix A and Appendix B). In addition, two studies used student performance in an OSCE to measure the success of the IPL simulation intervention in improving prescribing skills (Ragucci, 2014) and smoking cessation counselling skills (Efstathiou \& Walker, 2014). Furthermore, 
some studies included control groups so their institution's pre-existing single-profession intervention could be compared with the IPL-based simulation intervention (Saylor et al., 2016; Wamsley et al., 2012). Other studies compared the performance of interprofessional groups to single-profession groups undergoing the same simulation intervention, with the IPL groups outperforming the others (Clay et al., 2017; Scherer et al., 2013).

\section{Outcomes measured}

The vast majority of studies measured outcomes immediately following the IPL simulation intervention rather than longitudinal effects and sustainable outcomes of IPL, with 70 studies involving a single workshop or tutorial. The studies examining post-intervention educational outcomes mainly evaluated the effectiveness of their training in terms of learners' reactions to IPL immediately following the simulation intervention (JET Level 1: Reaction). However, some single workshops or tutorials did include a post-test questionnaire aimed at measuring the longitudinal impact of the IPL simulation intervention several months after the session. This demonstrated slight decay in both student knowledge and positive attitudes, but these did not decline completely back to the pre-test level (Kearney et al., 2010; McIlwaine et al., 2007). In addition, some studies used an initial simulation combined with a follow-up simulation, and these showed sustained improvement in performance and confidence with a slight decay compared to the immediate post-test level (Garbee et al., 2013; Nagelkerk et al., 2014; Reime, Johnsgaard, Kvam, Aarflot, Breivik, et al., 2016). For example, Garbee et al. (2013) incorporated two sets of two simulations 6 months apart and found that although some skills were forgotten between the two workshops, skills in communication, cooperation, coordination and situational awareness were rapidly regained in the later workshop between the first simulation and the second.

The most common outcome assessed was students' attitudes towards IPL, with 51 studies citing this as an assessed outcome (see Appendix A and Appendix B). The second most common outcome assessed was self-reported confidence in applying skills learnt from the IPL simulation intervention (21 studies). The third most common outcome was assessment by a supervisor of the teamwork skills performed by the group during the simulation intervention (10 studies).

One common outcome across all simulation interventions, regardless of the study methodology, was that students' preconceived notions or stereotypes of other professions was challenged (JET Level 2a: Modification of attitudes), particularly the hierarchy of decision making between doctors and nurses (S. Cooke et al., 2003; Holthaus et al., 2015; King et al., 2013; Lockeman et al., 2017; Rodehorst et al., 2005; Shanahan \& Lewis, 2015; Whelan et al., 2008). Salam et al.'s (2015) finding confirmed that post IPL simulation intervention, medical students strongly agreed that a nurse should be viewed as 
a collaborator and colleague rather than as a physician's assistant. Similarly, many studies reported an increased awareness of the roles of other healthcare professionals (Buckley et al., 2012; Flentje et al., 2016; Leithead et al., 2018; Motycka et al., 2018; Nagraj et al., 2018; Partecke et al., 2016; Pitout et al., 2014; Reeves et al., 2017; Rochman et al., 2012; Sehgal et al., 2019; Wen et al., 2019), an increased confidence in participants' teamwork and clinical skills (Atack et al., 2009; Joyal et al., 2015; Kumar, Gilmour, et al., 2014; Liaw, Siau, et al., 2014; Lippe et al., 2020; Luctkar-Flude, Baker, Pulling, et al., 2010; Tofil et al., 2014; Wakefield et al., 2006; Wamsley et al., 2012) and positive attitudes to working in interprofessional teams in the future (Anderson et al., 2017; Brock et al., 2013; Buckley et al., 2012; Dagnone et al., 2008; Efstathiou \& Walker, 2014; Kearney et al., 2010; Kumar, Wallace, et al., 2017; A. Miller et al., 2013; Reed et al., 2017; Robertson et al., 2010; Tofil et al., 2014; Wang et al., 2015). Overwhelmingly, student feedback indicated that they found IPL simulation interventions beneficial because of the opportunity to practise clinical (Efstathiou \& Walker, 2014; Haber et al., 2017; Kumar, Wallace, et al., 2017) and teamwork skills (Reed et al., 2017; Reising, Carr, Shea, \& King, 2011; Shaw-Battista et al., 2015; Stewart et al., 2010; van Schaik et al., 2016; West et al., 2015).

Another common outcome explored in many studies was whether providing student groups with formal team training prior to the IPL simulation intervention led to improved teamwork skills (Jakobsen et al., 2018; Luctkar-Flude, Baker, Medves, et al., 2013; Ragucci et al., 2016; Scherer et al., 2013; Sigalet, Donnon, Cheng, et al., 2013; Sigalet, Donnon, \& Grant, 2015; Wang et al., 2015). Luctkar-Flude, Baker, Medves, et al. (2013) found that nursing students who participated in an IPL training module with medical students before commencing the emergency paediatric life support simulation reported increased confidence in their teamwork skills. Similarly, Wang et al. (2015) found that nursing students who participated in an IPL training module with medical students before commencing surgical simulations also reported increased confidence in their procedural skills. In addition, Ragucci et al. (2016) found that IPL groups who attended a halfday workshop on error recognition and disclosure prior to the simulation intervention performed significantly more confidently than groups who did not. Similarly, Jankouskas et al. (2011) found that IPL groups of medical and nursing students who took part in a "Crisis Resource Management Team" training exercise before a basic life support simulation performed better than their peers. However, Sigalet, Donnon, Cheng, et al. (2013) detected that groups were able to significantly improve their teamwork skills by simply repeating the IPL simulation or participating in multiple IPL simulations, independent of prior training. Furthermore, two studies reported that there were no statistically significant differences between groups who did or did not receive training prior to simulation interventions (Hobgood et al., 2010; Luctkar-Flude, Baker, Pulling, et al., 2010), and two other studies reported that the act of participating in an IPL simulation was more significant in increasing 
THE USE OF INTERPROFESSIONAL SIMULATION INTERVENTIONS IN MEDICAL STUDENT EDUCATION

self-reported confidence and satisfaction in teamwork skills than a didactic pre-simulation workshop alone (Wamsley et al., 2012; Wang et al., 2015).

\section{Discussion}

This scoping review demonstrates that IPL with simulation is widely used to teach a variety of skills to medical students in conjunction with students from several different health professions, with varied simulation formats tailored to the specific skills and scenarios used in each simulation intervention.

The majority of IPL simulation interventions for medical students have nursing students as the other interprofessional group, suggesting there is scope for interventions designed for students from a broader range of health professions. Interventions with a greater mix of professional groups achieved more positive results (Atack et al., 2009; J. L. Miller et al., 2014). Although this was a smaller number of studies, the finding is in keeping with studies in the business sector, which show that diverse teams make better decisions (Nathan \& Lee, 2013). It may be because more diverse professional groups more accurately reflect the workplace.

While a variety of formats were used in IPL simulation interventions, high-fidelity simulations were the most common, despite also being the most costly. The evidence suggests that these scenarios improve students' interprofessional communication and teamwork skills immediately following the simulation intervention. However, these types of simulations in the IPL setting are usually heavily constrained by logistical and cost barriers, particularly regarding the synchronisation of timetables. There was large variation in the topic areas for learning in IPL simulation interventions, the most common topics being emergency medicine clinical skills (basic and advanced life support) and communication skills (see Appendix A and Appendix B).

The most common outcome of IPL simulation interventions was that students' attitudes towards IPL were positive. Students reported a greater understanding of the role of the other health professions, a more positive attitude towards interprofessional teamwork and increased confidence in their teamwork skills. On balance, a greater number of studies found that the student groups who were provided with formal team training prior to the IPL simulation intervention had higher levels of self-reported confidence in teamwork skills and had higher externally-rated team performance scores compared to groups without this extra training. However, some studies did not corroborate this correlation, and this discrepancy may be explained by the wide variety of tasks that are considered a simulation intervention.

The success of IPL simulation interventions was typically evaluated based upon improving the participants' perception of IPL, improving interprofessional teamwork skills, and improving communication skills (see Appendix A and Appendix B). These outcomes were 
most frequently evaluated based on subjective student experience, with self-reporting using standardised self-assessment tools completed immediately after the intervention. Therefore, the value of this information is limited in two ways. Firstly, the information is self-reported, and while there is reasonable evidence that students react positively to the opportunity to participate in IPL simulation interventions, there is only limited evidence that such an intervention improves student knowledge and skill in areas such as teamwork and communication. However, for the studies that did measure both self-reported and objective increase in interprofessional skills, these did positively correlate with improved skill level (Atack et al., 2009; Hegg et al., 2020; Krumwiede et al., 2019; Luctkar-Flude, Baker, Pulling, et al., 2010; Ragucci et al., 2016; Reese et al., 2010; Smithburger et al., 2013). Secondly, the vast majority of results were based on immediate post-test results (JET Level 1) rather than longitudinal effects and sustainable outcomes. This review demonstrates a gap in longer-term outcome measures. Whilst educators may intend for positive short-term outcomes in IPL to translate into tangible improvement in interprofessional capabilities within the workplace, evidence is lacking. Studies evaluating higher JET level outcomes would assist by providing evidence of long-term outcomes. However, this research is more difficult to undertake, and confounding from other variables prevents linkage of benefits to a single IPL intervention.

In terms of the limitations of this scoping review, the major difficulty lies in the broad interpretation of what is considered a "simulation intervention". As there is no general consensus on a definition for simulation intervention, this review includes simulation interventions of widely different formats that are not necessarily comparable. While the term simulation intervention neatly applies to interventions involving students practising clinical skills on a mannequin or simulated patient, this review has also included simulation interventions that refer to students participating in online case-based modules, working with virtual reality patients or simply observing discussions with no active participation. While these studies meet the eligibility criteria, they should potentially be considered as a separate category, and in the future, a clear definition for simulation intervention should be sought in order to prevent inappropriate comparisons and conclusions being made. Additionally, the majority of the evidence referred to in this review originates from studies with small sample sizes, and few studies provided sample size calculations. There is also potential for bias in terms of selectively reporting significant outcomes.

\section{Conclusion}

This scoping review summarises the existing literature on IPL using simulation for medical student education. The majority of IPL simulation interventions for medical students included nursing students and most commonly involved high-fidelity simulations of emergency scenarios. They also evaluated students' self-reported attitudes before and 
THE USE OF INTERPROFESSIONAL SIMULATION INTERVENTIONS IN MEDICAL STUDENT EDUCATION

immediately post-intervention (JET Level 1). Current evidence suggests that simulationbased interventions are effective in improving medical students' attitudes towards IPL and that formal team training prior to simulation is more effective in improving teamwork skills than simulation alone. IPL interventions with a greater mix of professions have more positive results, in keeping with studies of teams in other non-healthcare settings. Finally, this review highlights the gap in evidence of longer-term outcomes.

\section{Funding and conflicts of interest}

The authors report no conflicts of interest. The authors alone are responsible for the content and writing of this article. No funding was received for this study.

\section{References}

Al-Elq, A. H. (2010). Simulation-based medical teaching and learning. Journal of Family Community Medicine, 17(1), 35-40. https://doi.org/10.4103/1319-1683.68787

Anderson, G., Hughes, C., Patterson, D., \& Costa, J. (2017). Enhancing inter-professional education through low-fidelity simulation. British Journal of Midwifery, 25(1), 52-58. https://doi.org/10.12968/bjom.2017.25.1.52

Appelbaum, N. P., Lockeman, K. S., Orr, S., Huff, T. A., Hogan, C. J., Queen, B. A., \& Dow, A. W. (2020). Perceived influence of power distance, psychological safety, and team cohesion on team effectiveness. Journal of Interprofessional Care, 34(1), 20-26. http://se.org/10.1080/13561820.2019.1633290

Atack, L., Parker, K., Rocchi, M., Maher, J., \& Dryden, T. (2009). The impact of an online interprofessional course in disaster management competency and attitude towards interprofessional learning. Journal of Interprofessional Care, 23(6), 586-598. http://doi.org/10.3109/13561820902886238

Baker, C., Pulling, C., McGraw, R., Dagnone, J. D., Hopkins-Rosseel, D., \& Medves, J. (2008). Simulation in interprofessional education for patient-centred collaborative care. Journal of Advanced Nursing, 64(4), 372-379. https://doi.org/10.1111/j.13652648.2008.04798.x

Berg, B. W., Wong, L., \& Vincent, D. S. (2010). Technology-enabled interprofessional education for nursing and medical students: A pilot study. Journal of Interprofessional Care, 24(5), 601-604. http://doi.org/10.3109/13561820903373194

Blackhall, L. J., Erickson, J., Brashers, V., Owen, J., \& Thomas, S. (2014). Development and validation of a collaborative behaviors objective assessment tool for end-of-life communication. Journal of Palliative Medicine, 17(1), 68-74. https://doi.org/10.1089/ jpm.2013.0262 
THE USE OF INTERPROFESSIONAL SIMULATION INTERVENTIONS IN MEDICAL STUDENT EDUCATION

Bottenberg, M. M., DeWitt, J. E., Wall, G. C., Fornoff, A., Stelter, N., Soltis, D., \& Eastman, D. K. (2013). Assessment of interprofessional perceptions and attitudes of health professional students in a simulation laboratory setting. Currents in Pharmacy Teaching and Learning, 5(3), 167-174. https://doi.org/10.1016/j.cptl.2012.12.004

Brock, D., Abu-Rish, E., Chiu, C. R., Hammer, D., Wilson, S., Vorvick, L., Blondon, K., Schaad, D., Liner, D., \& Zierler, B. (2013). Interprofessional education in team communication: Working together to improve patient safety. BMJ Quality \& Safety, 22(5), 414-423. https://doi.org/10.1136/bmjqs-2012-000952

Brown, C. W., Howard, M., \& Morse, J. (2016). The use of trauma interprofessional simulated education (TIPSE) to enhance role awareness in the emergency department setting. Journal of Interprofessional Care, 30(3), 388-390. https://doi.org/10.3109/1356 $\underline{1820.2015 .1121216}$

Buckley, S., Hensman, M., Thomas, S., Dudley, R., Nevin, G., \& Coleman, J. (2012). Developing interprofessional simulation in the undergraduate setting: Experience with five different professional groups. Journal of Interprofessional Care, 26(5), 362-369. https://doi.org/10.3109/13561820.2012.685993

Clay, A. S., Chudgar, S. M., Turner, K. M., Vaughn, J., Knudsen, N. W., Farnan, J. M., Arora, V. M., \& Molloy, M. A. (2017). How prepared are medical and nursing students to identify common hazards in the intensive care unit? Annals of the American Thoracic Society, 14(4), 543-549. https://doi.org/10.1513/AnnalsATS.201610-7730C

Cooke, C., Gormley, G. J., Haughey, S., \& Barry, J. (2017). Tracing the prescription journey: A qualitative evaluation of an interprofessional simulation-based learning activity. Advances in Simulation, 2, Article 14. https://doi.org/10.1186/s41077-017-0047-0

Cooke, S., Wakefield, A., Chew-Graham, C., \& Boggis, C. (2003). Collaborative training in breaking bad news to patients. Journal of Interprofessional Care, 17(3), 307-309.

Dagnone, J. D., McGraw, R. C., Pulling, C. A., \& Patteson, A. K. (2008). Interprofessional resuscitation rounds: A teamwork approach to ACLS education. Medical Teacher, 30(2), e49-e54. https://doi.org/10.1080/01421590701769548

Djukic, M., Adams, J., Fulmer, T., Szyld, D., Lee, S., Oh, S. Y., \& Triola, M. (2015). E-learning with virtual teammates: A novel approach to interprofessional education. Journal of Interprofessional Care, 29(5), 476-482. https://doi.org/10.3109/13561820.20 $\underline{15.1030068}$ 
THE USE OF INTERPROFESSIONAL SIMULATION INTERVENTIONS IN MEDICAL STUDENT EDUCATION

Djukic, M., Fulmer, T., Adams, J. G., Lee, S., \& Triola, M. M. (2012). NYU3T: Teaching, technology, teamwork: A model for interprofessional education scalability and sustainability. Nursing Clinics of North America, 47(3), 333-346. https://doi. org/10.1016/j.cnur.2012.05.003

Efstathiou, N., \& Walker, W. M. (2014). Interprofessional, simulation-based training in end of life care communication: A pilot study. Journal of Interprofessional Care, 28(1), 68-70. https://doi.org/10.3109/13561820.2013.827163

Ellman, M. S., Schulman-Green, D., Blatt, L., Asher, S., Viveiros, D., Clark, J., \& Bia, M. (2012). Using online learning and interactive simulation to teach spiritual and cultural aspects of palliative care to interprofessional students. Journal of Palliative Medicine, 15(11), 1240-1247. https://doi.org/10.1089/jpm.2012.0038

Fewster-Thuente, L. (2014). A contemporary method to teach collaboration to students. Journal of Nursing Education, 53(11), 641-645. https://doi.org/10.3928/0148483420141027-02

Flentje, M., Mubel, T., Henzel, B., \& Jantzen, J.-P. (2016). Simulating a patient's fall as a means to improve routine communication: Joint training for nursing and fifth-year medical students. GMS Journal for Medical Education, 33(2), 1-13. https://doi. org/10.3205/zma001018

Freeth, D., Hammick, M., Reeves, S., Koppel, I., \& Barr, H. (2005). Effective interprofessional education: Development, delivery and evaluation. Blackwell. https://doi.org/10.1002/9780470776438

Garbee, D. D., Paige, J., Barrier, K., Kozmenko, V., Kozmenko, L., Zamjahn, J., Bonanno, L., \& Cefalu, J. (2013). Interprofessional teamwork among students in simulated codes: A quasi-experimental study. Nursing Education Perspectives, 34(5), 339-344. https://doi.org/10.5480/1536-5026-34.5.339

Gorantla, S., Bansal, U., Singh, J. V., Dwivedi, A. D., Malhotra, A., \& Kumar, A. (2019). Introduction of an undergraduate interprofessional simulation based skills training program in obstetrics and gynaecology in India. Advances in Simulation, 4, Article 6. https://doi.org/10.1186/s41077-019-0096-7

Greenstock, L. N., Brooks, P. M., Webb, G. R., \& Moran, M. C. (2012). Taking stock of interprofessional learning in Australia. Medical Journal of Australia, 196(11), 707-707. https://doi.org/10.5694/mja11.10919 
THE USE OF INTERPROFESSIONAL SIMULATION INTERVENTIONS IN MEDICAL STUDENT EDUCATION

Haber, J., Hartnett, E., Allen, K., Crowe, R., Adams, J., Bella, A., Riles, T., \& Vasilyeva, A. (2017). The impact of oral-systemic health on advancing interprofessional education outcomes. Journal of Dental Education, 81(2), 140-148. https://doi.org/10.1002/j.00220337.2017.81.2.tb06259.x

Hegg, R. M., Ivan, K. F., Tone, J., \& Morten, A. (2020). Comparison of peer assessment and faculty assessment in an interprofessional simulation-based team training program. Nurse Education in Practice, 42, Article 102666. https://doi.org/10.1016/j. nepr.2019.102666

Hess, R., Hagemeier, N. E., Blackwelder, R., Rose, D., Ansari, N., \& Branham, T. (2016). Teaching communication skills to medical and pharmacy students through a blended learning course. American Journal of Pharmaceutical Education, 80(4), 64. https://doi.org/10.5688/ajpe80464

Hobgood, C., Sherwood, G., Frush, K., Hollar, D., Maynard, L., Foster, B., Sawning, S., Woodyard, C. D., Durham, C., Wright, M., Taekman, J., on behalf of the Interprofessional Patient Safety Education Collaborative. (2010). Teamwork training with nursing and medical students: Does the method matter? Results of an interinstitutional, interdisciplinary collaboration. Quality \& Safety in Health Care, 19(6), e25. https://doi.org/10.1136/qshc.2008.031732

Holthaus, V., Sergakis, G., Rohrig, L., Wilcox, J., Thomas, E., McClerking, C., Legg, J., Clutter, J., \& Nahikian-Nelms, M. (2015). The impact of interprofessional simulation on dietetic student perception of communication, decision making, roles, and self-efficacy. Topics in Clinical Nutrition, 30(2), 127-142. https://doi.org/10.1097/ TIN.0000000000000027

Horsley, T. L., Reed, T., Muccino, K., Quinones, D., Siddall, V. J., \& McCarthy, J. (2016). Developing a foundation for interprofessional education within nursing and medical curricula. Nurse Education, 41(5), 234-238. https://doi.org/10.1097/ NNE.0000000000000255

Jakobsen, R. B., Gran, S. F., Grimsmo, B., Arntzen, K., Fosse, E., Frich, J. C., \& Hjortdahl, P. (2018). Examining participant perceptions of an interprofessional simulation-based trauma team training for medical and nursing students. Journal of Interprofessional Care, 32(1), 80-88. https://doi.org/10.1080/13561820.2017.1376625

Jankouskas, T. S., Haidet, K. K., Hupcey, J. E., Kolanowski, A., \& Murray, W. B. (2011). Targeted crisis resource management training improves performance among randomized nursing and medical students. Simulation Healthcare, 6(6), 316-326. https://doi.org/10.1097/SIH.0b013e31822bc676 
THE USE OF INTERPROFESSIONAL SIMULATION INTERVENTIONS IN MEDICAL STUDENT EDUCATION

Joyal, K. M., Katz, C., Harder, N., \& Dean, H. (2015). Interprofessional education using simulation of an overnight inpatient ward shift. Journal of Interprofessional Care, 29(3), 268-270. https://doi.org/10.3109/13561820.2014.944259

Kearney, A., Adey, T., Bursey, M., Cooze, L., Dillon, C., Barrett, J., King-Jesso, P., \& McCarthy, P. (2010). Enhancing patient safety through undergraduate inter-professional health education [Special issue]. Healthcare Quarterly, 13, 88-93. https://doi. org/10.12927/hcq.2010.21972

Ker, J. S., Mole, L., \& Bradley, P. (2003). Early introduction to interprofessional learning: A simulated ward environment. Medical Education, 37(3), 248-255. https://doi. org/10.1046/j.1365-2923.2003.01439.x

King, A. E., Conrad, M., \& Ahmed, R. A. (2013). Improving collaboration among medical, nursing and respiratory therapy students through interprofessional simulation. Journal of Interprofessional Care, 27(3), 269-271. https://doi.org/10.3109/13561820.2012.730076

Kirkpatrick, D. L. (2006). Seven keys to unlock the four levels of evaluation. Performance Improvement, 45(7), 5-8. https://doi.org/10.1002/pfi.2006.4930450702

Krumwiede, K. H., Wagner, J. M., Kirk, L. M., Duval, T. M., Dalton, T. O., Daniel, K. M., Huffman, A. S., Adams-Huet, B., \& Rubin, C. D. (2019). A team disclosure of error educational activity: Objective outcomes. Journal of the American Geriatrics Society, 67(6), 1273-1277. https://doi.org/10.1111/jgs.15883

Kumar, A., Gilmour, C., Nestel, D., Aldridge, R., McLelland, G., \& Wallace, E. (2014). Can we teach core clinical obstetrics and gynaecology skills using low fidelity simulation in an interprofessional setting? Australian and New Zealand Journal of Obstetrics and Gynaecology, 54(6), 589-592. https://doi.org/10.1111/ajo.12252

Kumar, A., Wallace, E. M., East, C., McClelland, G., Hall, H., Leech, M., \& Nestel, D. (2017). Interprofessional simulation-based education for medical and midwifery students: A qualitative study. Clinical Simulation in Nursing, 13(5), 217-227. https://doi.org/10.1016/j.ecns.2017.01.010

Kyrkjebo, J. M., Brattebo, G., \& Smith-Strom, H. (2006). Improving patient safety by using interprofessional simulation training in health professional education. Journal of Interprofessional Care, 20(5), 507-516. https://doi.org/10.1080/13561820600918200

Lawlis, T. R., Anson, J., \& Greenfield, D. (2014). Barriers and enablers that influence sustainable interprofessional education: A literature review. Journal of Interprofessional Care, 28(4), 305-310. https://doi.org/10.3109/13561820.2014.895977 
THE USE OF INTERPROFESSIONAL SIMULATION INTERVENTIONS IN MEDICAL STUDENT EDUCATION

Lee, W. J., Clark, L., Wortmann, K., Taylor, L. A., \& Pock, A. R. (2019). Interprofessional healthcare student training in the care of sexual assault patients utilizing standardized patient methodology. Simulation in Healthcare, 14(1), 10-17.https://doi.org/10.1097/ $\underline{\text { sih.0000000000000331 }}$

Leithead, J., III, Garbee, D. D., Yu, Q., Rusnak, V. V., Kiselov, V. J., Zhu, L., \& Paige, J. T. (2019). Examining interprofessional learning perceptions among students in a simulation-based operating room team training experience. Journal of Interprofessional Care, 33(1), 26-31. https://doi.org/10.1080/13561820.2018.1513464

Liaw, S. Y., Ooi, S. W., Rusli, K. D. B., Lau, T. C., Tam, W. W. S., \& Chua, W. L. (2020). Nurse-physician communication team training in virtual reality versus live simulations: Randomized controlled trial on team communication and teamwork attitudes. Journal of Medical Internet Research, 22(4), e17279. https://doi. org/10.2196/17279

Liaw, S. Y., Siau, C., Zhou, W. T., \& Lau, T. C. (2014). Interprofessional simulation-based education program: A promising approach for changing stereotypes and improving attitudes toward nurse-physician collaboration. Applied Nursing Research, 27(4), 258-260. https://doi.org/10.1016/j.apnr.2014.03.005

Lippe, M., Davis, A., Threadgill, H., \& Ricamato, A. (2020). Development of a new measure to assess primary palliative care perceived competence. Nurse Educator, 45(2), 106-110. https://doi.org/10.1097/nne.0000000000000682

Lockeman, K. S., Appelbaum, N. P., Dow, A. W., Orr, S., Huff, T. A., Hogan, C. J., \& Queen, B. A. (2017). The effect of an interprofessional simulation-based education program on perceptions and stereotypes of nursing and medical students: A quasi-experimental study. Nurse Education Today, 58, 32-37. https://doi.org/10.1016/j.nedt.2017.07.013

Luctkar-Flude, M., Baker, C., Medves, J., Tsai, E., Rivard, L., Goyer, M.-C., \& Krause, A. (2013). Evaluating an interprofessional pediatrics educational module using simulation. Clinical Simulation in Nursing, 9(5), e163-e169. https://doi.org/10.1016/j. ecns.2011.11.008

Luctkar-Flude, M., Baker, C., Pulling, C., McGraw, R., Dagnone, D., Medves, J., \& TurnerKelly, C. (2010). Evaluating an undergraduate interprofessional simulation-based educational module: Communication, teamwork, and confidence performing cardiac resuscitation skills. Advances in Medical Education and Practice, 1, 59-66. https://doi.org/10.2147/amep.S14100 
THE USE OF INTERPROFESSIONAL SIMULATION INTERVENTIONS IN MEDICAL STUDENT EDUCATION

McIlwaine, L., Scarlett, V., Venters, A., \& Ker, J. S. (2007). The different levels of learning about dying and death: An evaluation of a personal, professional and interprofessional learning journey. Medical Teacher, 29(6), e151-e159. https://doi. org/10.1080/01421590701294331

Miller, A., Morton, S., Sloan, P., \& Hashim, Z. (2013). Can a single brief intervention improve participants' readiness for interprofessional learning? Journal of Interprofessional Care, 27(6), 532-533. https://doi.org/10.3109/13561820.2013.805736

Miller, J. L., Rambeck, J. H., \& Snyder, A. (2014). Improving emergency preparedness system readiness through simulation and interprofessional education. Public Health Reports, 129(6, Suppl. 4), 129-135. https://doi.org/10.1177/00333549141296S417

Motycka, C., Egelund, E. F., Gannon, J., Genuardi, F., Gautam, S., Stittsworth, S., Young, A., \& Simon, L. (2018). Using interprofessional medication management simulations to impact student attitudes toward teamwork to prevent medication errors. Currents in Pharmacy Teaching and Learning, 10(7), 982-989. https://doi.org/10.1016/j. cptl.2018.04.010

Nagelkerk, J., Peterson, T., Pawl, B. L., Teman, S., Anyangu, A. C., Mlynarczyk, S., \& Baer, L. J. (2014). Patient safety culture transformation in a children's hospital: An interprofessional approach. Journal of Interprofessional Care, 28(4), 358-364. https://doi.org/10.3109/13561820.2014.885935

Nagraj, S., Harrison, J., Hill, L., Bowker, L., \& Lindqvist, S. (2018). Promoting collaboration in emergency medicine. The Clinical Teacher, 15(6), 500-505. https://doi.org/10.1111/ tct.12762

Nathan, M., \& Lee, N. (2013). Cultural diversity, innovation, and entrepreneurship: Firmlevel evidence from London. Economic Geography, 89(4), 367-394. https://doi. org/10.1111/ecge.12016

New, S. N., Huff, D. C., Hutchison, L. C., Bilbruck, T. J., Ragsdale, P. S., Jennings, J. E., \& Greenfield, M. (2015). Integrating collaborative interprofessional simulation into pre-licensure health care programs. Nursing Education Perspectives, 36(6), 396-397. https://doi.org/10.5480/13-1108

Nikendei, C., Huhn, D., Pittius, G., Trost, Y., Bugaj, T. J., Koechel, A., \& Schulz, J.-H. (2016). Students' perceptions on an interprofessional ward round training: A qualitative pilot study. GMS Journal for Medical Education, 33(2), Document 4. https://doi. org/10.3205/zma001013 
THE USE OF INTERPROFESSIONAL SIMULATION INTERVENTIONS IN MEDICAL STUDENT EDUCATION

Nystrom, S., Dahlberg, J., Edelbring, S., Hult, H., \& Dahlgren, M. A. (2016). Debriefing practices in interprofessional simulation with students: A sociomaterial perspective. BMC Medical Education, 16, Article 148. https://doi.org/10.1186/s12909-016-0666-5

Paige, J. T., Garbee, D. D., Kozmenko, V., Yu, Q., Kozmenko, L., Yang, T., Bonanno, \& Swartz, W. (2014). Getting a head start: High-fidelity, simulation-based operating room team training of interprofessional students. Journal of the American College of Surgeons, 218(1), 140-149. https://doi.org/10.1016/j.jamcollsurg.2013.09.006

Parsell, G., \& Bligh, J. (2002). The development of a questionnaire to assess the readiness of health care students for interprofessional learning (RIPLS). Medical Education, 33(2), 95-100. https://doi.org/10.1046/j.1365-2923.1999.00298.x

Partecke, M., Balzer, C., Finkenzeller, I., Reppenhagen, C., Hess, U., Hahnenkamp, K., \& Meissner, K. (2016). Interprofessional learning: Development and implementation of joint medical emergency team trainings for medical and nursing students at Universitätsmedizin Greifswald. GMS Journal for Medical Education, 33(2), Document 32. https://doi.org/10.3205/zma001031

Pitout, H., Human, A., Treadwell, I., \& Sobantu, N. A. (2014). Healthcare students' perceptions of a simulated interprofessional consultation in an outpatient clinic. Innovations in Education and Teaching International, 53(3), 338-348. https://doi.org/10.1080/14703297.2014.993417

Poore, J. A., Cullen, D. L., \& Schaar, G. L. (2014). Simulation-based interprofessional education guided by Kolb's experiential learning theory. Clinical Simulation in Nursing, 10(5), e241-e247. https://doi.org/10.1016/j.ecns.2014.01.004

Ragucci, K. R. (2014). Student evaluation of a clinical assessment course and related interprofessional simulation exercises. Currents in Pharmacy Teaching and Learning, 6(5), 692-698. https://doi.org/10.1016/j.cptl.2014.05.003

Ragucci, K. R., Kern, D. H., \& Shrader, S. P. (2016). Evaluation of interprofessional team disclosure of a medical error to a simulated patient. American Journal of Pharmaceutical Education, 80(8), Artilcle 138. https://doi.org/10.5688/ajpe808138

Reed, T., Horsley, T. L., Muccino, K., Quinones, D., Siddall, V. J., McCarthy, J., \& Adams, W. (2017). Simulation using teamSTEPPS to promote interprofessional education and collaborative practice. Nurse Educator, 42(3), e1-e5. https://doi.org/10.1097/ $\underline{\text { nne.0000000000000350 }}$ 
THE USE OF INTERPROFESSIONAL SIMULATION INTERVENTIONS IN MEDICAL STUDENT EDUCATION

Reese, C. E., Jeffries, P. R., \& Engum, S. A. (2010). Learning together: Using simulations to develop nursing and medical student collaboration. Nursing Education Perspectives, 31(1), 33-37.

Reeves, S. A., Denault, D., Huntington, J. T., Ogrinc, G., Southard, D. R., \& Vebell, R. (2017). Learning to overcome hierarchical pressures to achieve safer patient care: An interprofessional simulation for nursing, medical, and physician assistant students. Nurse Educator, 42(5, Suppl. 1), S27-S31. https://doi.org/10.1097/ NNE.0000000000000427

Reime, M. H., Johnsgaard, T., Kvam, F. I., Aarflot, M., Breivik, M., Engeberg, J. M., \& Brattebo, G. (2016). Simulated settings: Powerful arenas for learning patient safety practices and facilitating transference to clinical practice. A mixed method study. Nurse Education in Practice, 21, 75-82. https://doi.org/10.1016/j.nepr.2016.10.003

Reime, M. H., Johnsgaard, T., Kvam, F. I., Aarflot, M., Engeberg, J. M., Breivik, M., \& Brattebo, G. (2017). Learning by viewing versus learning by doing: A comparative study of observer and participant experiences during an interprofessional simulation training. Journal of Interprofessional Care, 31(1), 51-58. https://doi.org/10.1080/135618 $\underline{20.2016 .1233390}$

Reising, D. L., Carr, D. E., Shea, R. A., \& King, J. M. (2011). Comparison of communication outcomes in traditional versus simulation strategies in nursing and medical students. Nursing Education Perspectives, 32(5), 323-327.

Reising, D. L., Carr, D. E., Gindling, S., Barnes, R., Garletts, D., \& Ozdogan, Z. (2017). Team communication influence on procedure performance: Findings from interprofessional simulations with nursing and medical students. Nursing Education Perspectives, 38(5), 275-276. https://doi.org/10.1097/01.NEP.0000000000000168

Robertson, B., Kaplan, B., Atallah, H., Higgins, M., Lewitt, M. J., \& Ander, D. S. (2010). The use of simulation and a modified teamSTEPPS curriculum for medical and nursing student team training. Simulation in Healthcare, 5(6), 332-337. https://doi.org/10.1097/SIH.0b013e3181f008ad

Rochman, M. F., Aebersold, M., Tschannen, D., \& Cambridge, B. (2012). Interprofessional simulation on nurse interruptions. Journal of Nursing Care Quality, 27(3), 277-281. https://doi.org/10.1097/NCQ.0b013e31825734b4

Rodehorst, T. K., Wilhelm, S. L., \& Jensen, L. (2005). Use of interdisciplinary simulation to understand perceptions of team members' roles. Journal of Professional Nursing, 21(3), 159-166. https://doi.org/10.1016/j.profnurs.2005.04.005 
THE USE OF INTERPROFESSIONAL SIMULATION INTERVENTIONS IN MEDICAL STUDENT EDUCATION

Salam, T., Saylor, J. L., \& Cowperthwait, A. L. (2015). Attitudes of nurse and physician trainees towards an interprofessional simulated education experience on pain assessment and management. Journal of Interprofessional Care, 29(3), 276-278. https://doi.org/10.3109/13561820.2014.950726

Saylor, J., Vernoony, S., Selekman, J., \& Cowperthwait, A. (2016). Interprofessional education using a palliative care simulation. Nurse Educator, 41(3), 125-129. https://doi.org/10.1097/NNE.0000000000000228

Scherer, Y. K., Myers, J., O’Connor, T. D., \& Haskins, M. (2013). Interprofessional simulation to foster collaboration between nursing and medical students. Clinical Simulation in Nursing, 9(11), e497-e505. https://doi.org/10.1016/j.ecns.2013.03.001

Scott, A., Dawson, R. M., Mitchell, S., \& Catledge, C. (2020). Simulation-based interprofessional education in a rural setting: The development and evaluation of a “remote-in" telehealth scenario. Nursing Education Perspectives, 41(3), 187-189. https://doi.org/10.1097/01.Nep.0000000000000461

Sehgal, M., Nassetta, K. R., Bamdas, J. A. M., \& Sourial, M. (2019). First do no "pharm": Educating medical and pharmacy students on the essentials of medication management. Currents in Pharmacy Teaching and Learning, 11(9), 920-927. https://doi.org/10.1016/j.cptl.2019.05.006

Shanahan, C. A., \& Lewis, J. (2015). Perceptions of interprofessional clinical simulation among medical and nursing students: A pilot study. Journal of Interprofessional Care, 29(5), 504-506. https://doi.org/10.3109/13561820.2015.1027336

Shaw-Battista, J., Belew, C., Anderson, D., \& van Schaik, S. (2015). Successes and challenges of interprofessional physiologic birth and obstetric emergency simulations in a nurse-midwifery education program. Journal of Midwifery \& Women's Health, 60(6), 735-743. https://doi.org/10.1111/jmwh.12393

Shrader, S. S., Kern, D., Zoller, J., \& Blue, A. (2013). Interprofessional teamwork skills as predictors of clinical outcomes in a simulated healthcare setting. Journal of Allied Health, 42(1), e1-e6. https://www.uab.edu/simulation/images/Interprofessional_skills_ as_predictors.pdf

Shrader, S. S., McRae, L., King, W. M., \& Kern, D. (2011). A simulated interprofessional rounding experience in a clincal assessment course. American Journal of Pharmaceutical Education, 75(4), 8. https://doi.org/10.5688/ajpe75461 
THE USE OF INTERPROFESSIONAL SIMULATION INTERVENTIONS IN MEDICAL STUDENT EDUCATION

Sigalet, E., Donnon, T., Cheng, A., Cooke, S., Robinson, T., Bissett, W., \& Grant, V. (2013). Development of a team performance scale to assess undergraduate health professionals. Academic Medicine, 88(7), 989-996. https://doi.org/10.1097/ACM.0b013e318294fd45

Sigalet, E., Donnon, T., \& Grant, V. (2012). Undergraduate students' perceptions of and attitudes toward a simulation-based interprofessional curriculum: The KidSIM ATTITUDES questionnaire. Simulation in Healthcare, 7(6), 353-358. https://doi. org/10.1097/SIH.0b013e318264499e

Sigalet, E. L., Donnon, T. L., \& Grant, V. (2015). Insight into team competence in medical, nursing and respiratory therapy students. Journal of Interprofessional Care, 29(1), 62-67. https://doi.org/10.3109/13561820.2014.940416

Smithburger, P. L., Kane-Gill, S. L., Kloet, M. A., Lohr, B., \& Seybert, A. L. (2013). Avanzando la educacion interprofesional mediante el uso de simuladores de pacientes humanos de alta fidelidad [Advancing interprofessional education through the use of high fidelity human patient simulators]. Pharmacy Practice, 11(2), 61-65. https://doi.org/10.4321/S1886-36552013000200001

Stewart, M., Kennedy, N., \& Cuene-Grandidier, H. (2010). Undergraduate interprofessional education using high-fidelity paediatric simulation. The Clinical Teacher, 7(2), 90-96. https://doi.org/10.1111/j.1743-498X.2010.00351.X

Tankimovich, M., Swails, J., \& Hamburger, M. (2020). Nurse practitioner and medical students' perceptions of teamwork before and after a standardized patient pilot simulation. Nursing Education Perspectives, 41(3), 171-173. https://doi.org/10.1097/01. NEP.0000000000000503

Thistlethwaite, J., Kumar, K., Moran, M., Saunders, R., \& Carr, S. (2015). An exploratory review of pre-qualification interprofessional education evaluations. Journal of Interprofessional Care, 29(4), 292-297. https://doi.org/10.3109/13561820.2014.985292

Tofil, N. M., Morris, J. L., Peterson, D. T., Watts, P., Epps, C., Harrington, K. F., Leon, K., Pierce, C., \& White, M. L. (2014). Interprofessional simulation training improves knowledge and teamwork in nursing and medical students during internal medicine clerkship. Journal of Hospital Medicine, 9(3), 189-192. https://doi.org/10.1002/ jhm.2126

van Schaik, S. M., Regehr, G., Eva, K. W., Irby, D. M., \& O’Sullivan, P. S. (2016). Perceptions of peer-to-peer interprofessional feedback among students in the health professions. Academic Medicine, 91(6), 807-812. https://doi.org/10.1097/ acm.0000000000000981 
THE USE OF INTERPROFESSIONAL SIMULATION INTERVENTIONS IN MEDICAL STUDENT EDUCATION

Wagner, J., Liston, B., \& Miller, J. (2011). Developing interprofessional communication skills. Teaching and Learning in Nursing, 6(3), 97-101. https://doi.org/10.1016/ jteln.2010.12.003

Wakefield, A., Cooke, S., \& Boggis, C. (2003). Learning together: Use of simulated patients with nursing and medical students for breaking bad news. International Journal of Palliative Nursing, 9(1), 32-38. https://doi.org/10.12968/ijpn.2003.9.1.11043

Wakefield, A., Cocksedge, S., \& Boggis, C. (2006). Breaking bad news: Qualitative evaluation of an interprofessional learning opportunity. Medical Teacher, 28(1), 53-58. https://doi.org/10.1080/01421590500312805

Wamsley, M., Staves, J., Kroon, L., Topp, K., Hossaini, M., Newlin, B., Lindsay, C., O'Brien, B. (2012). The impact of an interprofessional standardized patient exercise on attitudes toward working in interprofessional teams. Journal of Interprofessional Care, 26(1), 28-35. https://doi.org/10.3109/13561820.2011.628425

Wang, R., Shi, N., Bai, J., Zheng, Y., \& Zhao, Y. (2015). Implementation and evaluation of an interprofessional simulation-based education program for undergraduate nursing students in operating room nursing education: A randomized controlled trial. $B M C$ Medical Education, 15, Article 115. https://doi.org/10.1186/s12909-015-0400-8

Wen, A., Wong, L., Ma, C., Arndt, R., Katz, A. R., Richardson, K., Deautsch, M., \& Masaki, K. (2019). An interprofessional team simulation exercise about a complex geriatric patient. Gerontology \& Geriatrics Education, 40(1), 16-29. https://doi.org/10.1080/027 $\underline{01960.2018 .1554568}$

West, C., Veronin, M., Landry, K., Kurz, T., Watzak, B., Quiram, B., \& Graham, L. (2015). Tools to investigate how interprofessional education activities link to competencies. Medical Education Online, 20(1), Article 28627. https://doi.org/10.3402/meo.v20.28627

Whelan, J. J., Spencer, J. F., \& Rooney, K. (2008). A “RIPPER” project: Advancing rural inter-professional health education at the University of Tasmania. Rural and Remote Health, 8(1017), 1-9.

World Health Organization (WHO). (2010). Framework for action on interprofessional education and collaborative practice. https://www.who.int/hrh/resources/framework action/en/ 
Appendix A

Summary of IPL Simulations Involving an Emergency Scenario Categorised by Format of Simulation

\begin{tabular}{|c|c|c|c|c|c|}
\hline Author & $\begin{array}{l}\text { Participants } \\
\text { (interprofessional } \\
\text { groups involved) }\end{array}$ & $\begin{array}{l}\text { Format of simulation } \\
\text { (no. and frequency of } \\
\text { intervention sessions) }\end{array}$ & $\begin{array}{l}\text { Outcome } \\
\text { assessment method }\end{array}$ & $\begin{array}{l}\text { Specific outcomes measured, as } \\
\text { classified by the JET model }\end{array}$ & Summary of key outcomes \\
\hline $\begin{array}{l}\text { Appelbaum et al. } \\
\text { (2020) }\end{array}$ & Medicine; nursing & 3 sessions & $\begin{array}{l}\text { Pre-post test } \\
\text { survey (developed by } \\
\text { researcher) }\end{array}$ & $\begin{array}{l}\text { Attitudes: towards teamwork, } \\
\text { power distance and } \\
\text { psychological safety }\end{array}$ & $\begin{array}{l}\text { Perceived power distance } \\
\text { impacted team effectiveness } \\
\text { through psychological safety and } \\
\text { perceived team cohesion. }\end{array}$ \\
\hline $\begin{array}{l}\text { Atack et al. } \\
(2009)\end{array}$ & $\begin{array}{l}\text { Medicine; } \\
\text { paramedicine; } \\
\text { nursing; social worker; } \\
\text { pharmacy; respiratory } \\
\text { therapist; medical } \\
\text { radiation }\end{array}$ & $\begin{array}{l}\text { 8-week course, } \\
\text { 3-hour weekly } \\
\text { modules }\end{array}$ & $\begin{array}{l}\text { Pre-post test } \\
\text { survey (RIPLS) }\end{array}$ & $\begin{array}{l}\text { Attitudes: perception of IPL } \\
\text { and disaster management } \\
\text { competencies }\end{array}$ & $\begin{array}{l}\text { Participants improved their } \\
\text { readiness to practise and } \\
\text { developed skills related to } \\
\text { interprofessional practice. }\end{array}$ \\
\hline $\begin{array}{l}\text { Baker et al. } \\
(2008)\end{array}$ & Medicine; nursing & Single session & Survey (IEPS) & $\begin{array}{l}\text { Attitude: perception of the } \\
\text { interprofessional team }\end{array}$ & $\begin{array}{l}\text { Participants felt they had a better } \\
\text { understanding of the roles in the } \\
\text { interprofessional team. }\end{array}$ \\
\hline $\begin{array}{l}\text { Bottenberg et al. } \\
\text { (2013) }\end{array}$ & $\begin{array}{l}\text { Medicine; nursing; } \\
\text { pharmacy }\end{array}$ & Single session & $\begin{array}{l}\text { Survey (developed } \\
\text { by researcher) }\end{array}$ & $\begin{array}{l}\text { Attitude: perception of } \\
\text { managing an emergency with } \\
\text { an interprofessional team }\end{array}$ & $\begin{array}{l}\text { Participants enjoyed the session, } \\
\text { but their attitudes were not } \\
\text { significantly altered by the } \\
\text { experience. }\end{array}$ \\
\hline $\begin{array}{l}\text { Buckley et al. } \\
\text { (2012) }\end{array}$ & $\begin{array}{l}\text { Medicine; nursing; } \\
\text { radiography; ODP; } \\
\text { physiotherapy }\end{array}$ & Single session & $\begin{array}{l}\text { Pre-post test survey } \\
\text { (developed by } \\
\text { researcher) }\end{array}$ & $\begin{array}{l}\text { Attitudes: confidence in } \\
\text { IPL, perception of factors } \\
\text { contributing to good care, } \\
\text { benefits of IPL to future clinical } \\
\text { practice and usefulness of } \\
\text { video feedback }\end{array}$ & $\begin{array}{l}\text { Participants felt more confident in } \\
\text { their team interactions. }\end{array}$ \\
\hline $\begin{array}{l}\text { Dagnone et al. } \\
(2008)\end{array}$ & Medicine; nursing & $\begin{array}{l}\text { Single session } \\
\text { ( } 2-4 \text { mini-sessions } \\
\text { combined) }\end{array}$ & $\begin{array}{l}\text { Post-test survey } \\
\text { (developed by } \\
\text { researcher) }\end{array}$ & $\begin{array}{l}\text { Attitude: perception of value of } \\
\text { the simulation }\end{array}$ & $\begin{array}{l}\text { Participants showed positive } \\
\text { attitudes towards the sessions. }\end{array}$ \\
\hline $\begin{array}{l}\text { Flentje et al. } \\
(2016)\end{array}$ & Medicine; nursing & Single session & $\begin{array}{l}\text { Post-test survey } \\
\text { (developed by } \\
\text { researcher) }\end{array}$ & $\begin{array}{l}\text { Attitude: towards importance of } \\
\text { IPL in professional practice }\end{array}$ & $\begin{array}{l}\text { Participants were more aware of } \\
\text { other healthcare professionals } \\
\text { following the intervention. }\end{array}$ \\
\hline
\end{tabular}




\begin{tabular}{|c|c|c|c|c|c|}
\hline Author & $\begin{array}{l}\text { Participants } \\
\text { (interprofessional } \\
\text { groups involved) }\end{array}$ & $\begin{array}{l}\text { Format of simulation } \\
\text { (no. and frequency of } \\
\text { intervention sessions) }\end{array}$ & $\begin{array}{l}\text { Outcome } \\
\text { assessment method }\end{array}$ & $\begin{array}{l}\text { Specific outcomes measured, as } \\
\text { classified by the JET model }\end{array}$ & Summary of key outcomes \\
\hline $\begin{array}{l}\text { Garbee et al. } \\
(2013)\end{array}$ & Medicine; nursing & $\begin{array}{l}\text { Two sessions over } \\
6 \text { months }\end{array}$ & $\begin{array}{l}\text { Survey (CATS, } \\
\text { TAS, \& Operating } \\
\text { Room Teamwork } \\
\text { Assessment Scale) }\end{array}$ & Skill: teamwork & $\begin{array}{l}\text { Teamwork skills improved, but } \\
\text { there was no statistically significant } \\
\text { difference } 6 \text { months later. }\end{array}$ \\
\hline $\begin{array}{l}\text { Hegg et al. } \\
(2020)\end{array}$ & Medicine; nursing & Single session & $\begin{array}{l}\text { Pre-post test survey } \\
\text { (developed by } \\
\text { researcher) }\end{array}$ & $\begin{array}{l}\text { Knowledge: ABCDE } \\
\text { assessment } \\
\text { Skills: teamwork and } \\
\text { communication }\end{array}$ & $\begin{array}{l}\text { Scores from peer observers } \\
\text { were generally lower on all } \\
\text { learning outcomes compared to } \\
\text { facilitators' scores. }\end{array}$ \\
\hline $\begin{array}{l}\text { Hobgood et al. } \\
(2010)\end{array}$ & Medicine; nursing & $\begin{array}{l}\text { Single session } \\
\text { Format: } \\
\text { TeamSTEPPS } \\
\text { teaching framework }\end{array}$ & $\begin{array}{l}\text { Survey (developed } \\
\text { by researcher) } \\
\text { SP evaluation } \\
\text { (unspecified) }\end{array}$ & $\begin{array}{l}\text { Attitudes: towards } \\
\text { interprofessional teamwork and } \\
\text { medical knowledge }\end{array}$ & $\begin{array}{l}\text { Participants' attitudes to teamwork } \\
\text { and knowledge scores improved } \\
\text { significantly. }\end{array}$ \\
\hline $\begin{array}{l}\text { Horsley et al. } \\
(2016)\end{array}$ & Medicine; nursing & $\begin{array}{l}\text { Single session } \\
(2 \text { mini sessions } \\
\text { combined }) \\
\text { Format: } \\
\text { TeamSTEPPS } \\
\text { teaching framework }\end{array}$ & $\begin{array}{l}\text { Checklist } \\
\text { (unspecified) }\end{array}$ & Skill: teamwork & $\begin{array}{l}\text { IPL was perceived to be extremely } \\
\text { valuable, and participants felt } \\
\text { the TeamSTEPPS principles } \\
\text { were useful. }\end{array}$ \\
\hline $\begin{array}{l}\text { Jakobsen et al. } \\
\text { (2018) }\end{array}$ & Medicine; nursing & $\begin{array}{l}\text { Single session } \\
\text { ( } 4 \text { mini sessions } \\
\text { combined) } \\
\text { Format: Better \& } \\
\text { Systematic Team } \\
\text { Training course to } \\
\text { students (Student- } \\
\text { BEST) }\end{array}$ & $\begin{array}{l}\text { Pre-post test survey } \\
\text { (developed by } \\
\text { researcher) }\end{array}$ & $\begin{array}{l}\text { Attitudes: towards teamwork } \\
\text { and communication }\end{array}$ & $\begin{array}{l}\text { Participants reported } \\
\text { increased understanding about } \\
\text { interprofessional communication, } \\
\text { teamwork and leadership. }\end{array}$ \\
\hline $\begin{array}{l}\text { Jankouskas et al. } \\
\text { (2011) }\end{array}$ & Medicine; nursing & $\begin{array}{l}\text { Single session } \\
\text { Format: Crisis } \\
\text { Resource } \\
\text { Management training }\end{array}$ & $\begin{array}{l}\text { Post-test survey } \\
\text { Basic Life Support } \\
\text { Checklist }\end{array}$ & Skill: teamwork & $\begin{array}{l}\text { No difference in team effectiveness } \\
\text { between control group and } \\
\text { intervention (crisis resource } \\
\text { management training). }\end{array}$ \\
\hline Joyal et al. (2015) & $\begin{array}{l}\text { Medicine; nursing; } \\
\text { pharmacy }\end{array}$ & Single session & $\begin{array}{l}\text { Pre-post test survey } \\
\text { (developed by } \\
\text { researcher) }\end{array}$ & $\begin{array}{l}\text { Attitude: confidence working in } \\
\text { an interprofessional team } \\
\text { Knowledge: interprofessional } \\
\text { knowledge (unspecified) }\end{array}$ & $\begin{array}{l}\text { Participants reported } \\
\text { improved knowledge about } \\
\text { other professional roles and } \\
\text { greater confidence working in } \\
\text { interprofessional teams. }\end{array}$ \\
\hline
\end{tabular}




\begin{tabular}{|c|c|c|c|c|c|}
\hline Author & $\begin{array}{l}\text { Participants } \\
\text { (interprofessional } \\
\text { groups involved) } \\
\end{array}$ & $\begin{array}{l}\text { Format of simulation } \\
\text { (no. and frequency of } \\
\text { intervention sessions) }\end{array}$ & $\begin{array}{l}\text { Outcome } \\
\text { assessment method }\end{array}$ & $\begin{array}{l}\text { Specific outcomes measured, as } \\
\text { classified by the JET model }\end{array}$ & Summary of key outcomes \\
\hline King et al. (2013) & $\begin{array}{l}\text { Medicine; nursing; } \\
\text { respiratory therapy }\end{array}$ & Single session & $\begin{array}{l}\text { Survey (developed } \\
\text { by researcher) }\end{array}$ & $\begin{array}{l}\text { Attitudes: towards } \\
\text { interprofessional teamwork and } \\
\text { roles of other professions }\end{array}$ & $\begin{array}{l}\text { Participants reported improved } \\
\text { awareness of the importance an } \\
\text { interprofessional team. }\end{array}$ \\
\hline $\begin{array}{l}\text { Kumar, Wallace, } \\
\text { et al. (2019) }\end{array}$ & Medicine; midwifery & Single session & $\begin{array}{l}\text { Pre-post test survey } \\
\text { (developed by } \\
\text { researcher) }\end{array}$ & $\begin{array}{l}\text { Attitudes: confidence working } \\
\text { in a team and towards effective } \\
\text { communication } \\
\text { Knowledge: procedural skills } \\
\text { and a systematic approach } \\
\text { to obstetric and neonatal } \\
\text { emergencies } \\
\text { Skill: teamwork }\end{array}$ & $\begin{array}{l}\text { Participants felt that team-based } \\
\text { learning could build trust between } \\
\text { professions, resulting in better } \\
\text { patient care. }\end{array}$ \\
\hline $\begin{array}{l}\text { Leithead et al. } \\
\text { (2018) }\end{array}$ & Medicine; nursing & Single session & $\begin{array}{l}\text { Pre-post test survey } \\
\text { (RIPLS) }\end{array}$ & $\begin{array}{l}\text { Attitude: towards IPL } \\
\text { Skill: teamwork }\end{array}$ & $\begin{array}{l}\text { Participants had significant } \\
\text { improvements in team-based } \\
\text { attitudes and RIPLS scores. }\end{array}$ \\
\hline $\begin{array}{l}\text { Liaw, Siau, et al. } \\
(2014)\end{array}$ & Medicine; nursing & $\begin{array}{l}\text { Single session } \\
(2 \text { mini sessions } \\
\text { combined) } \\
\text { Format: } \\
\text { TeamSTEPPS } \\
\text { teaching framework }\end{array}$ & $\begin{array}{l}\text { Pre-post test survey } \\
\text { (developed by } \\
\text { researcher) }\end{array}$ & $\begin{array}{l}\text { Attitude: towards } \\
\text { interprofessional collaboration }\end{array}$ & $\begin{array}{l}\text { Participants rated the } \\
\text { other profession higher for } \\
\text { interprofessional skills, academic } \\
\text { ability and being team players. }\end{array}$ \\
\hline $\begin{array}{l}\text { Liaw, Ooi, et al. } \\
(2020)\end{array}$ & Medicine; nursing & $\begin{array}{l}\text { Single session } \\
\text { Format: } \\
\text { TeamSTEPPS } \\
\text { teaching framework }\end{array}$ & $\begin{array}{l}\text { Pre-post test survey } \\
\text { (ATHCT survey \& } \\
\text { ISVS survey) }\end{array}$ & $\begin{array}{l}\text { Attitude: towards teamwork } \\
\text { Skill: communication skills }\end{array}$ & $\begin{array}{l}\text { Computer-based virtual reality was } \\
\text { not inferior to live simulations. }\end{array}$ \\
\hline $\begin{array}{l}\text { Lockeman et al. } \\
(2017)\end{array}$ & Medicine; nursing & 3 sessions & $\begin{array}{l}\text { Pre-post test survey } \\
\text { (developed by } \\
\text { researcher) }\end{array}$ & $\begin{array}{l}\text { Attitude: perception of working } \\
\text { in an interprofessional team } \\
\text { Knowledge: of IPL }\end{array}$ & $\begin{array}{l}\text { Participants had more positive } \\
\text { perceptions of interprofessional } \\
\text { practice. }\end{array}$ \\
\hline $\begin{array}{l}\text { Luctkar-Flude, } \\
\text { Baker, Pulling, et } \\
\text { al. (2010) }\end{array}$ & Medicine; nursing & Single session & $\begin{array}{l}\text { Post-test survey } \\
\text { (developed by } \\
\text { researcher) }\end{array}$ & $\begin{array}{l}\text { Attitudes: towards IPL and } \\
\text { confidence performing CPR } \\
\text { Skill: teamwork }\end{array}$ & $\begin{array}{l}\text { Interprofessional group reported } \\
\text { better communication and } \\
\text { greater confidence than } \\
\text { uniprofessional group (differences } \\
\text { not statistically significant). }\end{array}$ \\
\hline
\end{tabular}




\begin{tabular}{|c|c|c|c|c|c|}
\hline Author & $\begin{array}{l}\text { Participants } \\
\text { (interprofessional } \\
\text { groups involved) }\end{array}$ & $\begin{array}{l}\text { Format of simulation } \\
\text { (no. and frequency of } \\
\text { intervention sessions) }\end{array}$ & $\begin{array}{l}\text { Outcome } \\
\text { assessment method }\end{array}$ & $\begin{array}{l}\text { Specific outcomes measured, as } \\
\text { classified by the JET model }\end{array}$ & Summary of key outcomes \\
\hline $\begin{array}{l}\text { Luctkar-Flude, } \\
\text { Baker, Medves, } \\
\text { et al. (2013) }\end{array}$ & Medicine; nursing & $\begin{array}{l}\text { Single session } \\
(2 \text { mini sessions } \\
\text { combined })\end{array}$ & $\begin{array}{l}\text { Post-test survey } \\
\text { (developed by } \\
\text { researcher) } \\
\text { Checklist } \\
\text { (unspecified) }\end{array}$ & $\begin{array}{l}\text { Attitude: confidence performing } \\
\text { paediatric skills } \\
\text { Skill: teamwork }\end{array}$ & $\begin{array}{l}\text { Interprofessional group } \\
\text { reported less confidence } \\
\text { than uniprofessional group. } \\
\text { Interprofessional teams better at } \\
\text { role allocation than uniprofessional } \\
\text { teams. }\end{array}$ \\
\hline $\begin{array}{l}\text { Miller, Rambeck, } \\
\text { \& Snyder (2014) }\end{array}$ & $\begin{array}{l}\text { Medicine; nursing; } \\
\text { dentistry; pharmacy; } \\
\text { public health; } \\
\text { veterinary medicine }\end{array}$ & $\begin{array}{l}\text { Training over } \\
\text { semester of } 10 \\
\text { hours ( } 3 \text { workshops } \\
\& 2 \text { simulations) } \\
\text { Format: IPEC } \\
\text { based framework }\end{array}$ & Survey (IEPS) & $\begin{array}{l}\text { Skills: emergency response } \\
\text { and teamwork }\end{array}$ & $\begin{array}{l}\text { Participants demonstrated } \\
\text { significant improvement in } \\
\text { knowledge, teamwork and } \\
\text { emergency response skills. (Some } \\
\text { decay at follow-up.) }\end{array}$ \\
\hline $\begin{array}{l}\text { Nagelkerk et al. } \\
\text { (2014) }\end{array}$ & Medicine; nursing & Single session & $\begin{array}{l}\text { Survey (developed } \\
\text { by researcher) } \\
\text { Observation }\end{array}$ & $\begin{array}{l}\text { Attitude: towards } \\
\text { interprofessional teamwork } \\
\text { Knowledge: safety knowledge }\end{array}$ & $\begin{array}{l}\text { Participants safety-related } \\
\text { knowledge significantly increased, } \\
\text { and they felt their interprofessional } \\
\text { teamwork skills improved. }\end{array}$ \\
\hline $\begin{array}{l}\text { Nagraj et al. } \\
(2018)\end{array}$ & Medicine; paramedic & $\begin{array}{l}6 \text { sessions over } \\
2 \text { days }\end{array}$ & $\begin{array}{l}\text { Post-test survey } \\
\text { (developed by } \\
\text { researcher) }\end{array}$ & $\begin{array}{l}\text { Attitudes: towards teamwork } \\
\text { and IPL }\end{array}$ & $\begin{array}{l}\text { Increased knowledge of other } \\
\text { professions' role; enhanced mutual } \\
\text { respect; improved clinical skills and } \\
\text { collaborative practice. }\end{array}$ \\
\hline $\begin{array}{l}\text { Nystrom et al. } \\
(2016)\end{array}$ & Medicine; nursing & Single session & $\begin{array}{l}\text { Observation } \\
\text { Video analysis }\end{array}$ & $\begin{array}{l}\text { The difference in proximate and } \\
\text { distant observation of a student } \\
\text { simulation by their peers }\end{array}$ & $\begin{array}{l}\text { Proximate: participants took an } \\
\text { active role; instructors took more } \\
\text { traditional, didactic role. Distant: } \\
\text { participants more passive. }\end{array}$ \\
\hline $\begin{array}{l}\text { Partecke et al. } \\
\text { (2016) }\end{array}$ & Medicine; nursing & $\begin{array}{l}\text { Single session } \\
\text { (2-day course) }\end{array}$ & Observation & Attitude: towards IPL & $\begin{array}{l}\text { Participants' perceptions and } \\
\text { attitudes towards interprofessional } \\
\text { collaboration appeared to change } \\
\text { positively. }\end{array}$ \\
\hline $\begin{array}{l}\text { Pitout et al. } \\
(2016)\end{array}$ & $\begin{array}{l}\text { Medicine; } \\
\text { physiotherapy; } \\
\text { occupational therapy }\end{array}$ & Single session & Written reflection & $\begin{array}{l}\text { Attitude: towards working in an } \\
\text { interprofessional team }\end{array}$ & $\begin{array}{l}\text { Participants acknowledged the } \\
\text { importance of the interprofessional } \\
\text { team and recognised similarities/ } \\
\text { differences between roles. }\end{array}$ \\
\hline Reed et al. (2016) & Medicine; nursing & $\begin{array}{l}\text { Single session } \\
\text { Format: } \\
\text { TeamSTEPPS } \\
\text { teaching framework }\end{array}$ & $\begin{array}{l}\text { Post-test survey } \\
\text { (developed by } \\
\text { researcher) }\end{array}$ & $\begin{array}{l}\text { Attitude: towards managing } \\
\text { an emergency in an } \\
\text { interprofessional team }\end{array}$ & $\begin{array}{l}\text { Participants reported that } \\
\text { interprofessional collaboration } \\
\text { was an integral part of patient } \\
\text { care and safety. }\end{array}$ \\
\hline
\end{tabular}




\begin{tabular}{|c|c|c|c|c|c|}
\hline Author & $\begin{array}{l}\text { Participants } \\
\text { (interprofessional } \\
\text { groups involved) }\end{array}$ & $\begin{array}{l}\text { Format of simulation } \\
\text { (no. and frequency of } \\
\text { intervention sessions) }\end{array}$ & $\begin{array}{l}\text { Outcome } \\
\text { assessment method }\end{array}$ & $\begin{array}{l}\text { Specific outcomes measured, as } \\
\text { classified by the JET model }\end{array}$ & Summary of key outcomes \\
\hline $\begin{array}{l}\text { Reese et al. } \\
(2010)\end{array}$ & Medicine; nursing & Single session & Evaluation rubric & $\begin{array}{l}\text { Skill: teamwork in } \\
\text { disclosing error }\end{array}$ & $\begin{array}{l}\text { Participants were more } \\
\text { comfortable with explicit error } \\
\text { disclosure in a team. }\end{array}$ \\
\hline $\begin{array}{l}\text { Reime, } \\
\text { Johnsgaard, } \\
\text { Kvam, Aarflot, } \\
\text { Breivik, et al. } \\
\text { (2016) }\end{array}$ & Medicine; nursing & $\begin{array}{l}2 \text { sessions over } \\
7 \text { weeks }\end{array}$ & $\begin{array}{l}\text { Post-test survey } \\
\text { (Delphi performance } \\
\text { scale) } \\
\text { Focus groups } \\
\text { Peer assessment } \\
\text { (unspecified) }\end{array}$ & $\begin{array}{l}\text { Attitude: towards managing } \\
\text { an emergency in an } \\
\text { interprofessional team }\end{array}$ & $\begin{array}{l}\text { Participants reported learning to } \\
\text { speak up to ensure safe patient } \\
\text { care in an emergency. }\end{array}$ \\
\hline $\begin{array}{l}\text { Reime, } \\
\text { Johnsgaard, } \\
\text { Kvam, Aarflot, } \\
\text { Engeberg, et al. } \\
(2017)\end{array}$ & Medicine; nursing & $\begin{array}{l}2 \text { sessions over } \\
3 \text { months }\end{array}$ & $\begin{array}{l}\text { Post-test survey } \\
\text { (Delphi performance } \\
\text { scale) } \\
\text { Focus groups } \\
\text { Peer assessment } \\
\text { (unspecified) }\end{array}$ & $\begin{array}{l}\text { Attitudes: towards } \\
\text { interprofessional teamwork and } \\
\text { roles of other professions, and } \\
\text { confidence in communication }\end{array}$ & $\begin{array}{l}\text { Participants felt participating } \\
\text { in different roles and repeated } \\
\text { opportunities enhanced realism. }\end{array}$ \\
\hline $\begin{array}{l}\text { Reising, Carr, } \\
\text { Gindling, et al. } \\
(2017)\end{array}$ & Medicine; nursing & Single session & $\begin{array}{l}\text { Pre-post test survey } \\
\text { (IUSIR) }\end{array}$ & $\begin{array}{l}\text { Skills: communication and } \\
\text { procedure performance }\end{array}$ & $\begin{array}{l}\text { Improved interprofessional } \\
\text { team communication; improved } \\
\text { procedural performance; improved } \\
\text { patient care in the simulation setting. }\end{array}$ \\
\hline $\begin{array}{l}\text { Robertson et al. } \\
\text { (2010) }\end{array}$ & Medicine; nursing & $\begin{array}{l}\text { Single session } \\
\text { Format: } \\
\text { TeamSTEPPS } \\
\text { teaching framework }\end{array}$ & $\begin{array}{l}\text { Pre-post test survey } \\
\text { (developed by } \\
\text { researcher) }\end{array}$ & Attitude: towards IPL & $\begin{array}{l}\text { Participants' knowledge of } \\
\text { teamwork skills had improved. }\end{array}$ \\
\hline $\begin{array}{l}\text { Rodehorst et al. } \\
\text { (2005) }\end{array}$ & $\begin{array}{l}\text { Medicine; nursing; } \\
\text { respiratory therapy; } \\
\text { pharmacy }\end{array}$ & Single session & $\begin{array}{l}\text { Focus group } \\
\text { interviews }\end{array}$ & $\begin{array}{l}\text { Attitude: towards } \\
\text { interprofessional teamwork }\end{array}$ & $\begin{array}{l}\text { Recognised similarities/differences } \\
\text { between roles; challenged } \\
\text { attitudes about medical hierarchy; } \\
\text { improved sense of community } \\
\text { and teamwork. }\end{array}$ \\
\hline $\begin{array}{l}\text { Scherer et al. } \\
\text { (2013) }\end{array}$ & Medicine; nursing & Single session & $\begin{array}{l}\text { Pre-post test survey } \\
\text { (RIPLS) }\end{array}$ & $\begin{array}{l}\text { Attitude: towards IPL } \\
\text { Knowledge: of IPL } \\
\text { Skill: teamwork }\end{array}$ & $\begin{array}{l}\text { Participants from the } \\
\text { interprofessional group achieved } \\
\text { higher RIPLS survey scores than } \\
\text { the single profession group. }\end{array}$ \\
\hline
\end{tabular}




\begin{tabular}{|c|c|c|c|c|c|}
\hline Author & $\begin{array}{l}\text { Participants } \\
\text { (interprofessional } \\
\text { groups involved) }\end{array}$ & $\begin{array}{l}\text { Format of simulation } \\
\text { (no. and frequency of } \\
\text { intervention sessions) }\end{array}$ & $\begin{array}{l}\text { Outcome } \\
\text { assessment method }\end{array}$ & $\begin{array}{l}\text { Specific outcomes measured, as } \\
\text { classified by the JET model }\end{array}$ & Summary of key outcomes \\
\hline $\begin{array}{l}\text { Scott et al. } \\
(2020)\end{array}$ & $\begin{array}{l}\text { Medicine; nursing; } \\
\text { pharmacy }\end{array}$ & Single session & $\begin{array}{l}\text { Post-test survey } \\
\text { (developed by } \\
\text { researcher) }\end{array}$ & $\begin{array}{l}\text { Knowledge: of advanced life } \\
\text { support } \\
\text { Skill: teamwork }\end{array}$ & $\begin{array}{l}\text { Participants reported improved } \\
\text { teamwork skills and a better } \\
\text { understanding of other } \\
\text { professions' roles }\end{array}$ \\
\hline $\begin{array}{l}\text { Shanahan et al. } \\
\text { (2015) }\end{array}$ & Medicine; nursing & Single session & $\begin{array}{l}\text { Pre-post test survey } \\
\text { (developed by } \\
\text { researcher) }\end{array}$ & Attitude: towards IPL & $\begin{array}{l}\text { Participants increased their } \\
\text { understanding of the roles and } \\
\text { responsibilities of each profession. }\end{array}$ \\
\hline $\begin{array}{l}\text { Shaw-Battista et } \\
\text { al. (2015) }\end{array}$ & $\begin{array}{l}\text { Medicine; nursing; } \\
\text { midwifery }\end{array}$ & Unspecified & Written evaluation & Attitude: towards IPL & $\begin{array}{l}\text { The simulation intervention } \\
\text { appeared to improve team-based } \\
\text { learning and IPL specific to } \\
\text { maternity care. }\end{array}$ \\
\hline $\begin{array}{l}\text { Shrader, Kern, et } \\
\text { al. (2013) }\end{array}$ & $\begin{array}{l}\text { Medicine; pharmacy; } \\
\text { physician's assistant }\end{array}$ & $\begin{array}{l}\text { Single session } \\
\text { Format: IPEC- } \\
\text { based framework }\end{array}$ & $\begin{array}{l}\text { Survey (IEPS, TWS, } \\
\text { COS) }\end{array}$ & $\begin{array}{l}\text { Attitudes: perception of IPL and } \\
\text { clinical outcome, and teamwork } \\
\text { and clinical outcome }\end{array}$ & $\begin{array}{l}\text { Teamwork score was a significant } \\
\text { predictor of clinical outcomes scores. }\end{array}$ \\
\hline $\begin{array}{l}\text { Shrader, McRae } \\
\text { et al. (2011) }\end{array}$ & $\begin{array}{l}\text { Medicine; pharmacy; } \\
\text { physician's assistant }\end{array}$ & Single session & $\begin{array}{l}\text { Pre-post test survey } \\
\text { (IEPS, TWS, COS) }\end{array}$ & $\begin{array}{l}\text { Attitudes: perception of IPL and } \\
\text { clinical outcome, and teamwork } \\
\text { and clinical outcome }\end{array}$ & $\begin{array}{l}\text { Change in attitude to } \\
\text { interprofessional learning- } \\
\text { significantly more likely to agree } \\
\text { with particular survey statement. }\end{array}$ \\
\hline $\begin{array}{l}\text { Sigalet, Donnon, } \\
\text { Cheng, et al. } \\
(2013)\end{array}$ & $\begin{array}{l}\text { Medicine; nursing; } \\
\text { respiratory therapy }\end{array}$ & $\begin{array}{l}2 \text { sessions over } \\
2 \text { weeks }\end{array}$ & Survey (KIDSIM) & $\begin{array}{l}\text { The appropriateness of } \\
\text { the KIDSIM scoring tool for } \\
\text { the assessment of team } \\
\text { performance in IPL }\end{array}$ & $\begin{array}{l}\text { The intervention group scored } \\
\text { better than the comparison group } \\
\text { for each scenario. }\end{array}$ \\
\hline $\begin{array}{l}\text { Sigalet, Donnon, } \\
\text { \& Grant (2012) }\end{array}$ & $\begin{array}{l}\text { Medicine; nursing; } \\
\text { respiratory therapy }\end{array}$ & Single session & $\begin{array}{l}\text { Pre-post test } \\
\text { survey (ATTITUDES } \\
\text { Questionnaire) }\end{array}$ & $\begin{array}{l}\text { Attitude: towards } \\
\text { interprofessional teamwork }\end{array}$ & $\begin{array}{l}\text { Significantly increased: } \\
\text { relevance of IPL, relevance of } \\
\text { simulation, communication, } \\
\text { situational awareness, roles } \\
\text { and responsibilities. }\end{array}$ \\
\hline $\begin{array}{l}\text { Sigalet, Donnon, } \\
\text { \& Grant (2015) }\end{array}$ & $\begin{array}{l}\text { Medicine; nursing; } \\
\text { respiratory therapy }\end{array}$ & $\begin{array}{l}2 \text { sessions } \\
\text { (time unspecified) }\end{array}$ & Survey (KIDSIM) & Skill: teamwork & $\begin{array}{l}\text { The intervention group scored } \\
\text { better than comparison group for } \\
\text { each scenario. }\end{array}$ \\
\hline $\begin{array}{l}\text { Smithburger et } \\
\text { al. (2013) }\end{array}$ & $\begin{array}{l}\text { Medicine; pharmacy; } \\
\text { nursing; physician's } \\
\text { assistant; social work }\end{array}$ & 4 sessions, weekly & Survey (CATS) & Skill: teamwork & $\begin{array}{l}\text { The participants' communication } \\
\text { and teamwork skills significantly } \\
\text { improved. }\end{array}$ \\
\hline
\end{tabular}




\begin{tabular}{|c|c|c|c|c|c|}
\hline Author & $\begin{array}{l}\text { Participants } \\
\text { (interprofessional } \\
\text { groups involved) }\end{array}$ & $\begin{array}{l}\text { Format of simulation } \\
\text { (no. and frequency of } \\
\text { intervention sessions) }\end{array}$ & $\begin{array}{l}\text { Outcome } \\
\text { assessment method }\end{array}$ & $\begin{array}{l}\text { Specific outcomes measured, as } \\
\text { classified by the JET model }\end{array}$ & Summary of key outcomes \\
\hline $\begin{array}{l}\text { Stewart et al. } \\
\text { (2010) }\end{array}$ & Medicine; nursing & Single session & $\begin{array}{l}\text { Post-test survey } \\
\text { (developed by } \\
\text { researcher) }\end{array}$ & $\begin{array}{l}\text { Attitudes: perception of } \\
\text { knowledge, teamwork and } \\
\text { professional identity }\end{array}$ & $\begin{array}{l}\text { Participants reported } \\
\text { interprofessional simulation allowed } \\
\text { them to practise practical skills and } \\
\text { learn from other professions. }\end{array}$ \\
\hline $\begin{array}{l}\text { Tankimovich et } \\
\text { al. (2020) }\end{array}$ & Medicine; nursing & $\begin{array}{l}\text { Single session } \\
\text { Format: } \\
\text { TeamSTEPPS } \\
\text { teaching framework }\end{array}$ & $\begin{array}{l}\text { Pre-post test survey } \\
\text { (developed by } \\
\text { researcher) }\end{array}$ & $\begin{array}{l}\text { Attitudes: towards IPL and } \\
\text { teamwork }\end{array}$ & $\begin{array}{l}\text { Participants reported improved } \\
\text { confidence in their teamwork skills } \\
\text { and perceived interprofessional } \\
\text { team training as beneficial. }\end{array}$ \\
\hline Tofil et al. (2014) & Medicine; nursing & $\begin{array}{l}4 \text { sessions, } \\
\text { fortnightly }\end{array}$ & $\begin{array}{l}\text { Pre-post test survey } \\
\text { (developed by } \\
\text { researcher) }\end{array}$ & $\begin{array}{l}\text { Attitude: towards teamwork } \\
\text { Knowledge: medical } \\
\text { knowledge (unspecified) }\end{array}$ & $\begin{array}{l}\text { Participants knowledge scores } \\
\text { significantly improved, and they } \\
\text { had improved teamwork and } \\
\text { communication skills. }\end{array}$ \\
\hline $\begin{array}{l}\text { Wagner et al. } \\
\text { (2011) }\end{array}$ & Medicine; nursing & Single session & $\begin{array}{l}\text { Post-test survey } \\
\text { (developed by } \\
\text { researcher) }\end{array}$ & $\begin{array}{l}\text { Attitude: perception of working } \\
\text { in an interprofessional team }\end{array}$ & $\begin{array}{l}\text { Nursing more confident discussing } \\
\text { advanced care directives and } \\
\text { better prepared to work in an } \\
\text { interprofessional team. }\end{array}$ \\
\hline $\begin{array}{l}\text { Whelan et al. } \\
(2015)\end{array}$ & $\begin{array}{l}\text { Medicine; nursing; } \\
\text { pharmacy }\end{array}$ & Single session & $\begin{array}{l}\text { Pre-post test survey } \\
\text { (developed by } \\
\text { researcher) } \\
\text { Focus groups }\end{array}$ & $\begin{array}{l}\text { Knowledge: of the roles } \\
\text { and responsibilities of } \\
\text { health professionals }\end{array}$ & $\begin{array}{l}\text { Participants had a greater } \\
\text { appreciation of how } \\
\text { interprofessional collaboration can } \\
\text { lead to better patient care. }\end{array}$ \\
\hline
\end{tabular}

\section{Abbreviations:}

ATHCT: Attitudes Toward Interprofessional Health Care Team

ISVS: Interprofessional Socialization and Valuing Scale

RIPLS: Readiness for Interprofessional Learning Scale

IEPS: Interdisciplinary Education Perception Scale

CATS: Communication and Teamwork Skills assessment tool

TAS: $\quad$ Teamwork Assessment Scale

TWS: Teamwork Scale

COS: Clinical Outcome Scores

KIDSIM: KIDSIM team performance scale

IUSIR: Indiana University Simulation Integration Rubric 
Appendix B

Summary of IPL Simulations Involving Communication Skills Categorised by Format of Simulation

\begin{tabular}{|c|c|c|c|c|c|}
\hline Author & $\begin{array}{l}\text { Participants } \\
\text { (interprofessional } \\
\text { groups involved) }\end{array}$ & $\begin{array}{l}\text { Format of simulation } \\
\text { (no. and frequency of } \\
\text { intervention sessions) }\end{array}$ & $\begin{array}{l}\text { Outcome assessment } \\
\text { method }\end{array}$ & $\begin{array}{l}\text { Specific outcomes measured, as } \\
\text { classified by the JET model }\end{array}$ & Summary of key outcomes \\
\hline $\begin{array}{l}\text { Anderson et al. } \\
(2017)\end{array}$ & Medicine; midwifery & Single session & $\begin{array}{l}\text { Survey (developed } \\
\text { by researcher) }\end{array}$ & $\begin{array}{l}\text { Attitude: perception of } \\
\text { confidence of caring for a } \\
\text { woman in labour } \\
\text { Knowledge: understanding of } \\
\text { role of nurses and midwives }\end{array}$ & $\begin{array}{l}\text { Improved understanding of process } \\
\text { and others' roles; decreased } \\
\text { anxiety; positive interactions; } \\
\text { improved confidence working } \\
\text { with others. }\end{array}$ \\
\hline Berg et al. (2010) & Medicine; nursing & Single session & $\begin{array}{l}\text { Survey (developed } \\
\text { by researcher) } \\
\text { Checklist for SBAR } \\
\text { components }\end{array}$ & $\begin{array}{l}\text { Attitude: confidence in } \\
\text { using SBAR technique } \\
\text { to communicate with an } \\
\text { interprofessional team } \\
\text { Skill: adherence to } \\
\text { SBAR format }\end{array}$ & $\begin{array}{l}\text { Participants reported improved } \\
\text { understanding of interprofessional } \\
\text { communication but felt they lacked } \\
\text { skills to communicate appropriately. }\end{array}$ \\
\hline $\begin{array}{l}\text { Blackhall et al. } \\
\text { (2014) }\end{array}$ & Medicine; nursing & Unspecified & $\begin{array}{l}\text { Survey (developed } \\
\text { by researcher, } \\
\text { named CBOAT) }\end{array}$ & $\begin{array}{l}\text { Skills: professionalism, } \\
\text { communication, shared } \\
\text { problem solving and shared } \\
\text { decision making }\end{array}$ & $\begin{array}{l}\text { The final CBOAT assessment tool } \\
\text { clarified the important collaborative } \\
\text { behaviours needed by doctors } \\
\text { and nurses. }\end{array}$ \\
\hline $\begin{array}{l}\text { S. Cooke et al. } \\
\text { (2003) }\end{array}$ & Medicine; nursing & $\begin{array}{l}\text { Single session ( } 2- \\
\text { day course) }\end{array}$ & $\begin{array}{l}\text { Pre-post test survey } \\
\text { (developed by } \\
\text { researcher) } \\
\text { Reflective discussion }\end{array}$ & $\begin{array}{l}\text { Attitudes: confidence in } \\
\text { breaking bad news to } \\
\text { patients and towards } \\
\text { interprofessional teams }\end{array}$ & $\begin{array}{l}\text { Participants reported that the } \\
\text { experience had challenged } \\
\text { their preconceptions of the } \\
\text { other profession. }\end{array}$ \\
\hline $\begin{array}{l}\text { Djukic, Fulmer, et } \\
\text { al. (2012) }\end{array}$ & Medicine; nursing & $\begin{array}{l}\text { Single session (plus } \\
\text { 2-week } \\
\text { online module) } \\
\text { Format: } \\
\text { TeamSTEPPS } \\
\text { teaching framework } \\
\end{array}$ & $\begin{array}{l}\text { Survey (developed } \\
\text { by researcher) }\end{array}$ & Attitude: towards IPL & $\begin{array}{l}\text { Medical students appreciated being } \\
\text { introduced to the role of nurses and } \\
\text { enjoyed the experience overall. }\end{array}$ \\
\hline $\begin{array}{l}\text { Efstathiou \& } \\
\text { Walker (2014) }\end{array}$ & $\begin{array}{l}\text { Medicine; nursing; } \\
\text { pharmacy; } \\
\text { physiotherapy }\end{array}$ & $\begin{array}{l}\text { Single session } \\
\text { ( } 3 \text { mini-sessions } \\
\text { combined) } \\
\text { Format: IPEC } \\
\text { based framework }\end{array}$ & $\begin{array}{l}\text { Pre-post test survey } \\
\text { (RIPLS) }\end{array}$ & $\begin{array}{l}\text { Attitude: towards } \\
\text { interprofessional team } \\
\text { communication }\end{array}$ & $\begin{array}{l}\text { Participants felt more confident in } \\
\text { their skills and knowledge in dealing } \\
\text { with end-of-life communication. }\end{array}$ \\
\hline
\end{tabular}




\begin{tabular}{|c|c|c|c|c|c|}
\hline Author & $\begin{array}{l}\text { Participants } \\
\text { (interprofessional } \\
\text { groups involved) }\end{array}$ & $\begin{array}{l}\text { Format of simulation } \\
\text { (no. and frequency of } \\
\text { intervention sessions) }\end{array}$ & $\begin{array}{l}\text { Outcome assessment } \\
\text { method }\end{array}$ & $\begin{array}{l}\text { Specific outcomes measured, as } \\
\text { classified by the JET model }\end{array}$ & Summary of key outcomes \\
\hline $\begin{array}{l}\text { Ellman et al. } \\
(2012)\end{array}$ & $\begin{array}{l}\text { Medicine: nursing; } \\
\text { divinity }\end{array}$ & Single session & $\begin{array}{l}\text { Survey (developed } \\
\text { by researcher) }\end{array}$ & $\begin{array}{l}\text { Attitude: towards the } \\
\text { interprofessional team } \\
\text { Knowledge: understanding of } \\
\text { end-of-life care issues }\end{array}$ & $\begin{array}{l}\text { Recognised issues beyond } \\
\text { own discipline, roles of other } \\
\text { professionals and the value of } \\
\text { team collaboration. }\end{array}$ \\
\hline $\begin{array}{l}\text { Fewster-Thuente } \\
\text { et al. (2014) }\end{array}$ & Medicine; nursing & $\begin{array}{l}\text { Single session } \\
\text { (two mini sessions } \\
\text { combined) } \\
\text { Format: } \\
\text { TeamSTEPPS } \\
\text { teaching framework }\end{array}$ & $\begin{array}{l}\text { Pre-post test survey } \\
\text { (developed by } \\
\text { researcher) }\end{array}$ & $\begin{array}{l}\text { Attitude: towards } \\
\text { interprofessional team } \\
\text { communication }\end{array}$ & $\begin{array}{l}\text { Participants reported having a } \\
\text { better understanding of each } \\
\text { other's role. }\end{array}$ \\
\hline Hess et al. (2016) & Medicine; pharmacy & $\begin{array}{l}\text { Training over } \\
\text { semester ( } 5 \\
\text { sessions \& } 10 \\
\text { online modules) }\end{array}$ & $\begin{array}{l}\text { OSCE prepost } \\
\text { intervention } \\
\text { (Common Ground } \\
\text { Rating OSCE } \\
\text { assessment tool) }\end{array}$ & Skill: patient interviewing skills & $\begin{array}{l}\text { Performance in all communication } \\
\text { skill domains increased significantly. }\end{array}$ \\
\hline $\begin{array}{l}\text { Holthaus et al. } \\
\text { (2015) }\end{array}$ & $\begin{array}{l}\text { Medicine; nursing; } \\
\text { dietetics; physical } \\
\text { therapy; respiratory } \\
\text { therapy; pharmacy; } \\
\text { occupational therapy; } \\
\text { social work }\end{array}$ & Single session & $\begin{array}{l}\text { Pre-post test survey } \\
\text { (RIPLS) }\end{array}$ & $\begin{array}{l}\text { Attitudes: towards other } \\
\text { professions and perception } \\
\text { of IPL }\end{array}$ & $\begin{array}{l}\text { Greater understanding of } \\
\text { other professions' roles. More } \\
\text { comfortable working and } \\
\text { communicating as a team. }\end{array}$ \\
\hline $\begin{array}{l}\text { Kearney et al. } \\
(2010)\end{array}$ & $\begin{array}{l}\text { Medicine; nursing; } \\
\text { pharmacy }\end{array}$ & Single session & $\begin{array}{l}\text { Survey (developed } \\
\text { by researcher) }\end{array}$ & $\begin{array}{l}\text { Attitudes: towards adverse } \\
\text { event disclosure and } \\
\text { perception of IPL } \\
\text { Knowledge: understanding } \\
\text { interprofessional teamwork } \\
\text { and patient safety }\end{array}$ & $\begin{array}{l}\text { Positive attitude towards teamwork } \\
\text { and interprofessional collaboration. } \\
\text { Increased understanding of } \\
\text { adverse event reporting. }\end{array}$ \\
\hline Ker et al. (2003) & Medicine; nursing & Single session & $\begin{array}{l}\text { Survey (developed } \\
\text { by researcher) }\end{array}$ & $\begin{array}{l}\text { Skills: collaborative teamwork } \\
\text { and effective leadership }\end{array}$ & $\begin{array}{l}\text { Participants enjoyed integrating } \\
\text { their learning in a safe environment. } \\
\text { Observers noted that collaborative } \\
\text { teamwork increased. }\end{array}$ \\
\hline
\end{tabular}




\begin{tabular}{|c|c|c|c|c|c|}
\hline Author & $\begin{array}{l}\text { Participants } \\
\text { (interprofessional } \\
\text { groups involved) }\end{array}$ & $\begin{array}{l}\text { Format of simulation } \\
\text { (no. and frequency of } \\
\text { intervention sessions) }\end{array}$ & $\begin{array}{l}\text { Outcome assessment } \\
\text { method }\end{array}$ & $\begin{array}{l}\text { Specific outcomes measured, as } \\
\text { classified by the JET model }\end{array}$ & Summary of key outcomes \\
\hline King et al. (2009) & $\begin{array}{l}\text { Medicine; nursing; } \\
\text { dentistry; laboratory } \\
\text { science; nutrition; } \\
\text { occupational therapy; } \\
\text { pharmacy; physical } \\
\text { therapy }\end{array}$ & $\begin{array}{l}2 \text { sessions per } \\
\text { week for } 5 \text { weeks }\end{array}$ & $\begin{array}{l}\text { Surveillance of } \\
\text { program usage data }\end{array}$ & $\begin{array}{l}\text { Usage of the online resources } \\
\text { by health students }\end{array}$ & $\begin{array}{l}\text { Use of the online resources } \\
\text { dropped each week over the } \\
5 \text { weeks. }\end{array}$ \\
\hline $\begin{array}{l}\text { Krumwiede et al. } \\
\text { (2019) }\end{array}$ & $\begin{array}{l}\text { Medicine; nursing; } \\
\text { clinical nutrition; } \\
\text { prosthetics/orthotics; } \\
\text { physical therapy; } \\
\text { physician's assistants; } \\
\text { radiation therapy; } \\
\text { social work }\end{array}$ & Single session & $\begin{array}{l}\text { Pre-post test survey } \\
\text { (developed by } \\
\text { researcher) }\end{array}$ & $\begin{array}{l}\text { Attitudes: towards IPL and } \\
\text { teamwork } \\
\text { Knowledge: error disclosure }\end{array}$ & $\begin{array}{l}\text { More comfortable with disclosing } \\
\text { a medical error. Positive } \\
\text { attitude towards team roles } \\
\text { and responsibilities. }\end{array}$ \\
\hline Lee et al. (2019) & Medicine; nursing & Single session & $\begin{array}{l}\text { Pre-post test survey } \\
\text { (developed by } \\
\text { researcher) }\end{array}$ & $\begin{array}{l}\text { Attitude: confidence in } \\
\text { assessing sexual assault } \\
\text { patients } \\
\text { Knowledge: understanding of } \\
\text { a sexual assault assessment } \\
\text { Skill: communication with } \\
\text { sexual assault patients }\end{array}$ & $\begin{array}{l}\text { Confidence in sexual assault } \\
\text { assessment rose significantly } \\
\text { post intervention. }\end{array}$ \\
\hline $\begin{array}{l}\text { Liaw, Siau, et al. } \\
\text { (2014) }\end{array}$ & Medicine; nursing & $\begin{array}{l}\text { Single session } \\
\text { Format: } \\
\text { TeamSTEPPS } \\
\text { teaching framework }\end{array}$ & $\begin{array}{l}\text { Pre-post test survey } \\
\text { (developed by } \\
\text { researcher) }\end{array}$ & $\begin{array}{l}\text { Attitudes: perception of IPL } \\
\text { and confidence in working in } \\
\text { an interprofessional team }\end{array}$ & $\begin{array}{l}\text { Significant improvement in the } \\
\text { participants' scores for perceptions } \\
\text { of IPL and self-confidence in } \\
\text { verbal communication. }\end{array}$ \\
\hline Lippe et al. (2020) & $\begin{array}{l}\text { Medicine; nursing; } \\
\text { social work }\end{array}$ & Single session & $\begin{array}{l}\text { Pre-post test survey } \\
\text { (CARES-PC) }\end{array}$ & $\begin{array}{l}\text { The appropriateness of the } \\
\text { CARES-PC scoring tool for } \\
\text { the assessment of perceived } \\
\text { competency in palliative care }\end{array}$ & $\begin{array}{l}\text { The CARES-PC tool demonstrated } \\
\text { strong reliability/validity. It captured } \\
\text { change in perceived competence. }\end{array}$ \\
\hline $\begin{array}{l}\text { Mcllwaine et al. } \\
\text { (2007) }\end{array}$ & Medicine; social work & Single session & $\begin{array}{l}\text { Survey (developed } \\
\text { by researcher) }\end{array}$ & $\begin{array}{l}\text { Attitude: towards } \\
\text { interprofessional teamwork }\end{array}$ & $\begin{array}{l}\text { Participants awareness of their } \\
\text { professional role and knowledge of } \\
\text { other health professionals' } \\
\text { roles improved. }\end{array}$ \\
\hline $\begin{array}{l}\text { A. Miller et al. } \\
\text { (2013) }\end{array}$ & Medicine; nursing & Single session & $\begin{array}{l}\text { Pre-post test survey } \\
\text { (RIPLS) }\end{array}$ & Attitude: perception of IPL & $\begin{array}{l}\text { Participants' attitudes became } \\
\text { more positive, but this did not reach } \\
\text { statistical significance. }\end{array}$ \\
\hline
\end{tabular}




\begin{tabular}{|c|c|c|c|c|c|}
\hline Author & $\begin{array}{l}\text { Participants } \\
\text { (interprofessional } \\
\text { groups involved) }\end{array}$ & $\begin{array}{l}\text { Format of simulation } \\
\text { (no. and frequency of } \\
\text { intervention sessions) }\end{array}$ & $\begin{array}{l}\text { Outcome assessment } \\
\text { method }\end{array}$ & $\begin{array}{l}\text { Specific outcomes measured, as } \\
\text { classified by the JET model }\end{array}$ & Summary of key outcomes \\
\hline $\begin{array}{l}\text { Motycka et al. } \\
(2018)\end{array}$ & $\begin{array}{l}\text { Medicine; nursing; } \\
\text { pharmacy }\end{array}$ & $\begin{array}{l}\text { Single session } \\
\text { Format: } \\
\text { TeamSTEPPS } \\
\text { teaching framework }\end{array}$ & $\begin{array}{l}\text { Pre-post test survey } \\
\text { (TTAQ) }\end{array}$ & $\begin{array}{l}\text { Attitude: towards roles of } \\
\text { other professions } \\
\text { Skill: communication }\end{array}$ & $\begin{array}{l}\text { All participants communication } \\
\text { scores increased. The } \\
\text { interprofessional teams } \\
\text { became more proficient with } \\
\text { increased practice. }\end{array}$ \\
\hline New et al. (2015) & $\begin{array}{l}\text { Medicine; nursing; } \\
\text { pharmacy }\end{array}$ & Single session & $\begin{array}{l}\text { Survey (developed } \\
\text { by researcher) }\end{array}$ & $\begin{array}{l}\text { Attitude: perception of } \\
\text { benefit of intervention for } \\
\text { improving interprofessional } \\
\text { communication }\end{array}$ & $\begin{array}{l}\text { Participants from all professions } \\
\text { indicated that the intervention was } \\
\text { helpful and effective. }\end{array}$ \\
\hline $\begin{array}{l}\text { Ragucci et al. } \\
\text { (2016) }\end{array}$ & $\begin{array}{l}\text { Medicine; nursing; } \\
\text { pharmacy; physician's } \\
\text { assistant }\end{array}$ & Single session & $\begin{array}{l}\text { Survey (developed } \\
\text { by researcher) } \\
\text { Assessment rubric } \\
\text { post intervention }\end{array}$ & $\begin{array}{l}\text { Attitude: confidence in } \\
\text { disclosing medical errors to } \\
\text { patients } \\
\text { Skill: proficiency in disclosing } \\
\text { medical errors to patients }\end{array}$ & $\begin{array}{l}\text { Participants with training were } \\
\text { more comfortable with explicit error } \\
\text { disclosure and more likely } \\
\text { to apologise. }\end{array}$ \\
\hline $\begin{array}{l}\text { Reeves et al. } \\
\text { (2017) }\end{array}$ & $\begin{array}{l}\text { Medicine; nursing; } \\
\text { physician's assistant }\end{array}$ & Single session & $\begin{array}{l}\text { Post-test survey } \\
\text { (developed by } \\
\text { researcher) }\end{array}$ & $\begin{array}{l}\text { Attitude: towards teamwork } \\
\text { Skill: communication }\end{array}$ & $\begin{array}{l}\text { Increased confidence in applying } \\
\text { communication strategies and } \\
\text { effectiveness of team function. } \\
\text { Enjoyed learning about } \\
\text { professional roles. }\end{array}$ \\
\hline $\begin{array}{l}\text { Rochman et al. } \\
\text { (2012) }\end{array}$ & $\begin{array}{l}\text { Medicine; nursing; } \\
\text { public health; } \\
\text { engineering; business }\end{array}$ & $\begin{array}{l}\text { Single session } \\
(3 \text { mini sessions } \\
\text { combined) }\end{array}$ & $\begin{array}{l}\text { Survey (developed } \\
\text { by researcher) }\end{array}$ & $\begin{array}{l}\text { Knowledge: impact of } \\
\text { distractions and interruptions } \\
\text { on nurses }\end{array}$ & $\begin{array}{l}\text { Participants developed a more } \\
\text { detailed appreciation of the role of } \\
\text { the nurse and their challenges. }\end{array}$ \\
\hline $\begin{array}{l}\text { Saylor et al. } \\
\text { (2016) }\end{array}$ & Medicine; nursing & Single session & $\begin{array}{l}\text { Pre-post test survey } \\
\text { (developed by } \\
\text { researcher) }\end{array}$ & $\begin{array}{l}\text { Attitude: towards } \\
\text { interprofessional collaboration } \\
\text { Skill: interprofessional } \\
\text { competencies }\end{array}$ & $\begin{array}{l}\text { Participants developed a more } \\
\text { detailed appreciation of the role of } \\
\text { the nurse and their challenges. }\end{array}$ \\
\hline $\begin{array}{l}\text { Sehgal et al. } \\
\text { (2019) }\end{array}$ & Medicine; pharmacy & $\begin{array}{l}\text { Single session } \\
(2 \text { mini sessions } \\
\text { combined) } \\
\text { Format: IPEC } \\
\text { based framework }\end{array}$ & $\begin{array}{l}\text { Post intervention } \\
\text { reflection }\end{array}$ & $\begin{array}{l}\text { Attitude: towards } \\
\text { interprofessional teamwork }\end{array}$ & $\begin{array}{l}\text { Participants recognised their } \\
\text { profession's limitations. Participants } \\
\text { recognised the importance of } \\
\text { interprofessional collaboration. }\end{array}$ \\
\hline $\begin{array}{l}\text { van Schaik et al. } \\
(2016)\end{array}$ & $\begin{array}{l}\text { Medicine; nursing; } \\
\text { pharmacy; dentistry; } \\
\text { physical therapy; social } \\
\text { work; dietetics }\end{array}$ & Single session & $\begin{array}{l}\text { Survey (developed } \\
\text { by researcher) }\end{array}$ & $\begin{array}{l}\text { Attitude: towards usefulness } \\
\text { of feedback }\end{array}$ & $\begin{array}{l}\text { Participants found the concept of } \\
\text { giving peer feedback challenging } \\
\text { but useful. }\end{array}$ \\
\hline
\end{tabular}




\begin{tabular}{|c|c|c|c|c|c|}
\hline Author & $\begin{array}{l}\text { Participants } \\
\text { (interprofessional } \\
\text { groups involved) }\end{array}$ & $\begin{array}{l}\text { Format of simulation } \\
\text { (no. and frequency of } \\
\text { intervention sessions) }\end{array}$ & $\begin{array}{l}\text { Outcome assessment } \\
\text { method }\end{array}$ & $\begin{array}{l}\text { Specific outcomes measured, as } \\
\text { classified by the JET model }\end{array}$ & Summary of key outcomes \\
\hline $\begin{array}{l}\text { Wakefield et al. } \\
\text { (2006) }\end{array}$ & Medicine; nursing & Single session & $\begin{array}{l}\text { Pre-post test survey } \\
\text { (developed by } \\
\text { researcher) }\end{array}$ & $\begin{array}{l}\text { Attitude: towards } \\
\text { interprofessional teamwork } \\
\text { Skill: confidence in breaking } \\
\text { bad news }\end{array}$ & $\begin{array}{l}\text { Participants discovered similarities } \\
\text { and differences between roles and } \\
\text { that differences in roles could lead } \\
\text { to interprofessional conflict. }\end{array}$ \\
\hline $\begin{array}{l}\text { Wakefield et al. } \\
\text { (2003) }\end{array}$ & Medicine; nursing & $\begin{array}{l}\text { Single session } \\
\text { ( } 2 \text { mini sessions } \\
\text { combined) }\end{array}$ & $\begin{array}{l}\text { Pre-post test survey } \\
\text { (developed by } \\
\text { researcher) }\end{array}$ & $\begin{array}{l}\text { Attitude: towards } \\
\text { interprofessional teamwork } \\
\text { Skill: confidence in breaking } \\
\text { bad news }\end{array}$ & $\begin{array}{l}\text { Participants reported increased } \\
\text { confidence in their ability to break } \\
\text { bad news to patients. }\end{array}$ \\
\hline $\begin{array}{l}\text { Wamsley et al. } \\
\text { (2012) }\end{array}$ & $\begin{array}{l}\text { Medicine; nursing; } \\
\text { dentistry; pharmacy; } \\
\text { physical therapy }\end{array}$ & Single session & $\begin{array}{l}\text { Pre-post test survey } \\
\text { (ATHCT survey) }\end{array}$ & $\begin{array}{l}\text { Attitude: towards } \\
\text { interprofessional teamwork }\end{array}$ & $\begin{array}{l}\text { Greater appreciation for different } \\
\text { professional roles. Increased } \\
\text { perception of team value and } \\
\text { team efficiency. }\end{array}$ \\
\hline Wang et al. (2017) & Medicine; nursing & $\begin{array}{l}\text { Single session } \\
\text { Format: } \\
\text { TeamSTEPPS } \\
\text { teaching framework }\end{array}$ & $\begin{array}{l}\text { Pre-post test survey } \\
\text { (developed by } \\
\text { researcher) }\end{array}$ & $\begin{array}{l}\text { Knowledge: understanding of } \\
\text { the roles and responsibilities } \\
\text { of different professions }\end{array}$ & $\begin{array}{l}\text { Participants felt they learned to } \\
\text { operate in interprofessional teams } \\
\text { and recognised the importance } \\
\text { of collaboration. }\end{array}$ \\
\hline Wen et al. (2019) & $\begin{array}{l}\text { Medicine; nursing; } \\
\text { pharmacy; social work }\end{array}$ & $\begin{array}{l}\text { Single session } \\
\text { Format: IPEC } \\
\text { based framework }\end{array}$ & $\begin{array}{l}\text { Pre-post test survey } \\
\text { (developed by } \\
\text { researcher) }\end{array}$ & $\begin{array}{l}\text { Attitudes: towards teamwork } \\
\text { and interprofessional } \\
\text { communication }\end{array}$ & $\begin{array}{l}\text { Improved confidence in } \\
\text { communication. Increased } \\
\text { trust in other professions. } \\
\text { Increased appreciation for other } \\
\text { professions' abilities. }\end{array}$ \\
\hline
\end{tabular}

RIPLS: Readiness for Interprofessional Learning Scale

IEPS: Interdisciplinary Education Perception Scale

ATHCT: Attitudes Towards Healthcare Teams survey

TTAQ: Teamwork Attitudes Questionnaire

(1)

